\title{
Annual Hanford Seismic Report for Fiscal Year 2008
}

Pacific Northwest National Laboratory

Hanford Seismic Assessment Team

AC Rohay

RE Clayton

MD Sweeney

JL Devary

DC Hartshorn

December 2008 


\title{
DISCLAIMER
}

This report was prepared as an account of work sponsored by an agency of the United States Government. Neither the United States Government nor any agency thereof, nor Battelle Memorial Institute, nor any of their employees, makes any warranty, express or implied, or assumes any legal liability or responsibility for the accuracy, completeness, or usefulness of any information, apparatus, product, or process diselosed, or represents that its use would not infringe privately owned rights. Reference herein to any specific commercial product, process, or service by trade name, trademark, manufacturer, or otherwise does not necessarily constitute or imply its endorsement, recommendation, or favoring by the United States Government or any agency thereof, or Battelle Memorial Institute. The views and opinions of authors expressed herein do not necessarily state or reflect those of the United States Government or any agency thereof.

\author{
PACIFIC NORTHWEST NATIONAL LABORATORY \\ operated by \\ BATTELLE \\ for the \\ UNITED STATES DEPARTMENT OF ENERGY \\ under Contract DE-AC05-76RL01830 \\ Printed in the United States of America \\ Available to DOE and DOE contractors from the \\ Office of Scientific and Technical Information, \\ P.O. Box 62, Oak Ridge, TN 37831-0062; \\ ph: (865) 576-8401 \\ fax: (865) 576-5728 \\ email: reports@adonis.osti.gov

\footnotetext{
Available to the public from the National Technical Information Service, U.S. Department of Commerce, 5285 Port Royal Rd., Springfield, VA 22161 ph: (800) 553-6847 fax: (703) 605-6900 email: orders@ntis.fedworld.gov online ordering: http://www.ntis.gov/ordering.htm
} 
PNNL-18134

\title{
Annual Hanford Seismic Report for Fiscal Year 2008
}

\author{
A. C. Rohay \\ M. D. Sweeney \\ D. C. Hartshorn \\ R. E. Clayton \\ J. L. Devary
}

December 2008

Prepared for

the U.S. Department of Energy

under Contract DE-AC05-76RL01830

Pacific Northwest National Laboratory

Richland, Washington 99352 


\section{Summary}

The Hanford Seismic Assessment Program (HSAP) provides an uninterrupted collection of highquality raw and processed seismic data from the Hanford Seismic Network for the U.S. Department of Energy and its contractors. The HSAP is responsible for locating and identifying sources of seismic activity and monitoring changes in the historical pattern of seismic activity at the Hanford Site. The data are compiled, archived, and published for use by the Hanford Site for waste management, natural phenomena hazards assessments, and engineering design and construction. In addition, the HSAP works with the Hanford Site Emergency Services Organization to provide assistance in the event of a significant earthquake on the Hanford Site. The Hanford Seismic Network and the Eastern Washington Regional Network consist of 44 individual sensor sites and 15 radio relay sites maintained by the Hanford Seismic Assessment Team. This includes three recently acquired Transportable Array stations located at Cold Creek, Didier Farms, and Phinney Hill.

During fiscal year 2008, the Hanford Seismic Network recorded 1431 triggers on the seismometer system, which included 112 seismic events in the southeast Washington area and an additional 422 regional and teleseismic events. There were 74 events determined to be local earthquakes relevant to the Hanford Site. The highest-magnitude event (3.7 $\left.M_{c}\right)$ occurred on May 18, 2008, and was located approximately $17 \mathrm{~km}$ east of Prosser at a depth of $20.5 \mathrm{~km}$. With regard to the depth distribution, 13 earthquakes were located at shallow depths (less than $4 \mathrm{~km}$, most likely in the Columbia River basalts), 45 earthquakes were located at intermediate depths (between 4 and $9 \mathrm{~km}$, most likely in the prebasalt sediments), and 16 earthquakes were located at depths greater than $9 \mathrm{~km}$, within the crystalline basement. Geographically, 54 earthquakes were located in swarm areas and 20 earthquakes were classified as random events.

The May 18 earthquake was the highest magnitude event recorded since 1975 in the vicinity of the Hanford Site (between $46-47^{\circ}$ north latitude and $119-120^{\circ}$ west longitude). The event was not reported as being felt on the Hanford Site or causing any damage and was communicated to the Pacific Northwest National Laboratory Operations Center per HSAP communications procedures. The event is not considered to be significant with regard to site safety and not unprecedented given the site's seismic history.

The Hanford strong motion accelerometer (SMA) stations at the 200 East Area, 300 Area, and 400 Area were triggered by the May 18 event. The maximum acceleration recorded at the SMA stations $(0.17 \%$ at the 300 Area) was 12 times smaller than the reportable action level (2\% g) for Hanford Site facilities. 


\section{Abbreviations and Acronyms}

$\begin{array}{ll}\text { BWIP } & \text { Basalt Waste Isolation Project } \\ \text { CRBG } & \text { Columbia River Basalt Group } \\ \text { DOE } & \text { U.S. Department of Energy } \\ \text { ETNA } & \text { strong motion accelerometer manufactured by Kinemetrics } \\ \text { EWRN } & \text { Eastern Washington Regional Network } \\ \text { FY } & \text { fiscal year } \\ \text { GPRS } & \text { General Packet Radio Service } \\ \text { GPS } & \text { Global Positioning System } \\ \text { HSAP } & \text { Hanford Seismic Assessment Program } \\ \text { HSN } & \text { Hanford Seismic Network } \\ \text { M }_{\mathrm{C}} & \text { coda-length magnitude } \\ \text { M }_{\mathrm{L}} & \text { local magnitude } \\ \text { PNNL } & \text { Pacific Northwest National Laboratory } \\ \text { SMA } & \text { strong motion accelerometer } \\ \text { USGS } & \text { U.S. Geological Survey } \\ \text { UTC } & \text { Coordinated Universal Time } \\ \text { UW } & \text { University of Washington } \\ \text { WHC } & \text { Westinghouse Hanford Company }\end{array}$




\section{Contents}

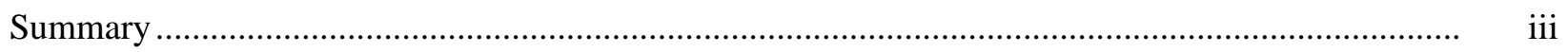

Abbreviations and Acronyms ….............................................................................................

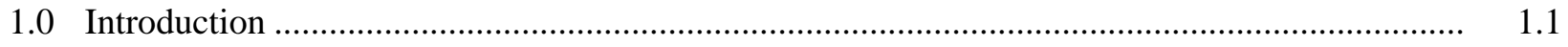

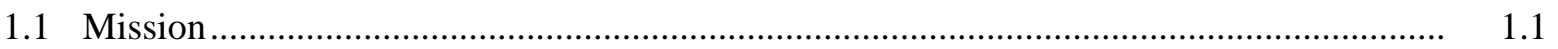

1.2 History of Monitoring Seismic Activity at Hanford .................................................... 1.1

1.3 Documentation and Reports ...................................................................................... 1.2

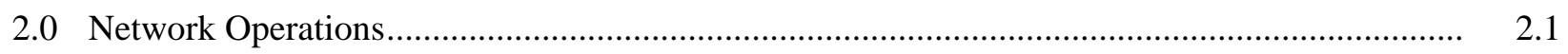

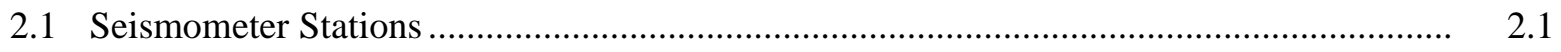

2.1.1 Station Maintenance .......................................................................................... 2.6

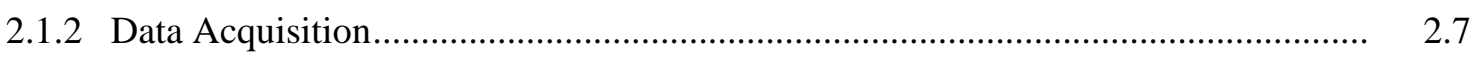

2.2 Strong Motion Accelerometer Stations ......................................................................... 2.8

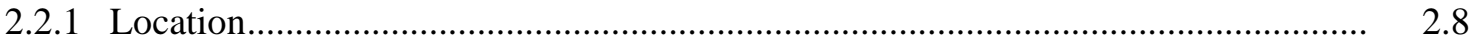

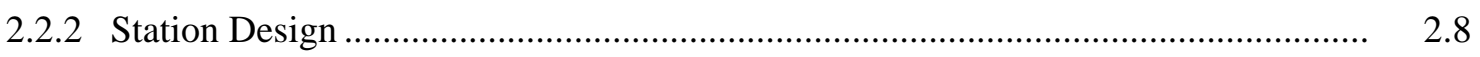

2.2.3 Strong Motion Accelerometer Operations Center ................................................. 2.10

2.2.4 Strong Motion Operational Characteristics ............................................................. 2.10

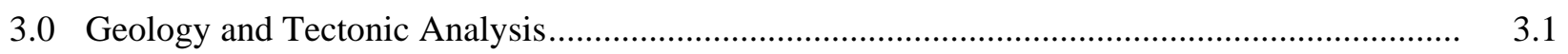

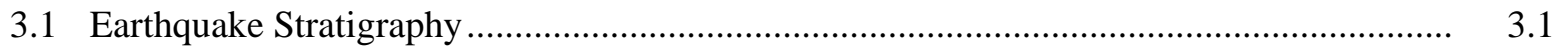

3.2 Geologic Structure Beneath the Monitored Area .......................................................... 3.1

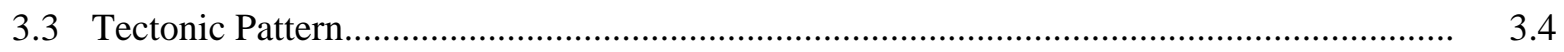

4.0 Earthquake Catalog Description ..........................................................................................

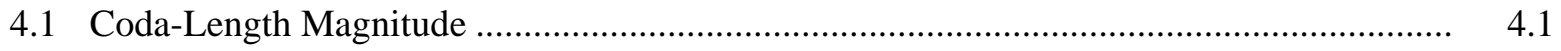

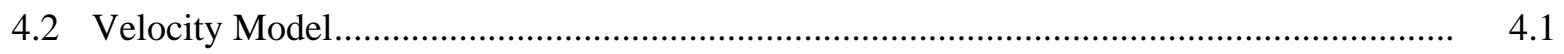

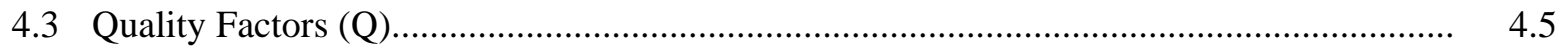

$5.0 \quad$ Seismic Activity - FY 2008 ...................................................................................... 5.1

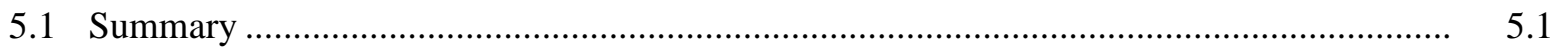

5.2 First Quarter FY 2008 Earthquakes ......................................................................... 5.2

5.2.1 Location and Depth of Earthquakes ..................................................................... 5.3

5.2.2 Major Anticlinal Ridges .................................................................................. 5.3

5.2.3 Earthquake Swarm Areas ...................................................................................... 5.3

5.2.4 Random or Floating Events ................................................................................. 5.3

5.3 Second Quarter FY 2008 Earthquakes …....................................................................... 5.3

5.3.1 Location and Depth of Earthquakes .................................................................. 5.4

5.3.2 Major Anticlinal Ridges ..................................................................................... 5.4

5.3.3 Earthquake Swarm Areas ......................................................................... 5.4

5.3.4 Random or Floating Events ....................................................................... 5.4 
5.4 Third Quarter FY 2008 Earthquakes ........................................................................... 5.4

5.4.1 Location and Depth of Earthquakes .................................................................. 5.5

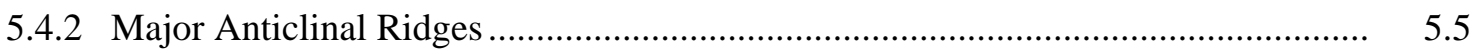

5.4.3 Earthquake Swarm Areas ................................................................................. 5.5

5.4.4 Random or Floating Events ................................................................................... 5.5

5.5 Fourth Quarter FY 2008 Earthquakes ...................................................................... 5.5

5.5.1 Location and Depth of Earthquakes .................................................................. 5.6

5.5.2 Major Anticlinal Ridges ................................................................................... 5.6

5.5.3 Earthquake Swarm Areas ............................................................................ 5.6

5.5.4 Random or Floating Events ........................................................................... 5.6

6.0 Strong Motion Accelerometer Operations ................................................................................ 6.1

6.1 Fourth Quarter FY 2008 Triggers of the Hanford SMA Network .................................... 6.1

6.2 FY 2008 Triggers of the Hanford SMA Network .......................................................... 6.1

7.0 Capabilities in the Event of a Significant Earthquake ...........................................................

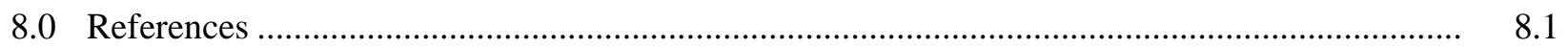




\section{Figures}

2.1 Seismometer and Strong Motion Accelerometer Stations in the Hanford Seismic

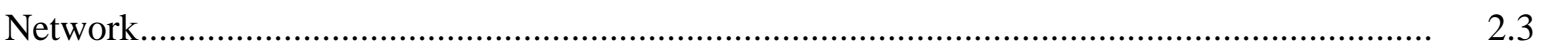

2.2 Seismometer Stations in the Eastern Washington Regional Network ....................................... 2.5

2.3 White Bluffs behind May Junction site (MJ2) ...................................................................... 2.6

2.4 Schematic Diagram of a Strong Motion Accelerometer Installation ........................................ 2.10

3.1 Physical and Structural Geology of the Hanford Site, Washington ........................................ 3.2

3.2 Geologic Cross Sections through the Columbia Basin (Reidel et al. 1994).............................. 3.3

5.1 FY 2008 Earthquakes Recorded Within the Hanford Monitoring Area .................................... 5.2

5.2 Earthquakes Occurring in the Hanford Monitoring Area Between July 1, 2008

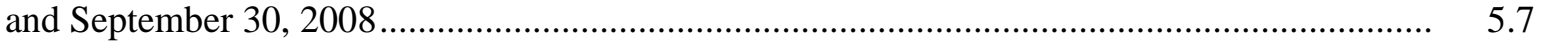

5.3 Cross-Sectional Depiction of Earthquakes Occurring in the Hanford Monitoring

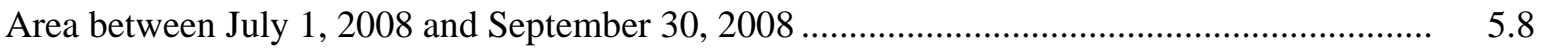

6.1 July 14, 2008 Acceleration Time Histories at 400 Area SMA from Maupin, Oregon,

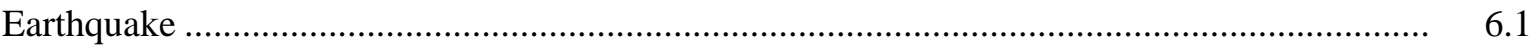

6.2 February 3, 2008 Micro Earthquake Acceleration Time Histories at 400 Area SMA............... 6.2

6.3 May 18, 2008 Micro Earthquake Acceleration Time Histories at 300 Area SMA .................... 6.3

6.4 Shake Map of May 18, 2008 Event (courtesy of Pacific Northwest Seismic Center) ................ $\quad 6.4$

\section{Tables}

2.1 Seismometer Stations in the Hanford Seismic Network ...................................................... 2.2

2.2 Seismometer Stations in the Eastern Washington Regional Network ....................................... 2.4

2.3 Free-Field Strong Motion Accelerometer Sites ....................................................................... 2.8

2.4 Instrument Parameters for the Kinemetrics ETNA System in the Hanford SMA

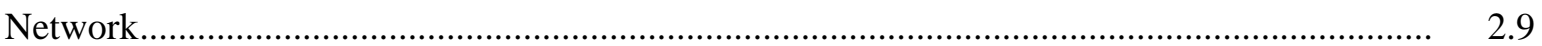

3.1 Thicknesses of Stratigraphic Units in the Monitoring Area..................................................... 3.4

4.1 Local Seismic Data, October 1, 2007 - September 30, 2008................................................ 4.2

4.2 Crustal Velocity Model for Eastern Washington ...................................................................

5.1 Depth Distribution of Earthquakes for FY08 .................................................................... 5.1

5.2 Earthquake Locations for FY 2008 ....................................................................................... 


\subsection{Introduction}

This annual report documents the locations, magnitudes, and seismic interpretations of earthquakes recorded for the Hanford monitoring region of south-central Washington during fiscal year (FY) 2008 (October 2007 through September 2008). The report provides summaries of seismic events recorded during the first three quarters of FY 2008 and a more comprehensive discussion of seismic events for the fourth quarter of FY 2008. Comprehensive discussions of seismic events recorded during the first three quarters of FY 2008 may be found in previously published quarterly reports (Rohay et al. 2008a, 2008b, 2008c).

\subsection{Mission}

The principal mission of the Hanford Seismic Assessment Program (HSAP) is to maintain the seismometer and strong motion accelerometer (SMA) sites, report data from measured events, and provide assistance in the event of an earthquake. This mission supports the U.S. Department of Energy (DOE) and the other Hanford Site contractors in their compliance with DOE Order 420.1B, Chapter IV, Section 3.d "Seismic Detection" and DOE Order G 420.1-1, Section 4.7, "Emergency Preparedness and Emergency Communications.” DOE Order 420.1B requires facilities or sites with hazardous materials to maintain instrumentation or other means to detect and record the occurrence and severity of the seismic event. The HSAP maintains the seismic network located on and around the Hanford Site. The data collected from the seismic network can be used to support facility or site operations to protect the public, workers, and the environment from the impact of seismic events.

In addition, the HSAP provides an uninterrupted collection of high-quality raw seismic data from the Hanford Seismic Network (HSN) and the Eastern Washington Regional Network (EWRN) and provides interpretations of seismic events from the Hanford Site and the vicinity. The program locates and identifies sources of seismic activity, monitors changes in the historical pattern of seismic activity, and builds a "local" earthquake database (processed data) that is permanently archived. The focus of this report is the precise location of earthquakes proximal to or on the Hanford Site, specifically, between 46-47 ${ }^{\circ}$ north latitude and between $119-120^{\circ}$ west longitude. Data from the EWRN and other seismic networks in the northwest provide the HSAP with necessary regional input for the seismic hazards analysis at the Hanford Site. These seismic data are used to support Hanford Site contractors for waste management activities, natural phenomena hazards assessments, and engineering design and construction.

\subsection{History of Monitoring Seismic Activity at Hanford}

Assessing seismic activity at the Hanford Site was initiated in 1969 by the U.S. Geological Survey (USGS) under a contract with the U.S. Atomic Energy Commission. In 1975, the University of Washington (UW) assumed responsibility for the network and subsequently expanded it. In 1979, the Basalt Waste Isolation Project (BWIP) became responsible for collecting seismic data for the Hanford Site as part of site characterization activities. Rockwell Hanford Operations, followed by Westinghouse Hanford Company (WHC), operated the local network and were the contract technical advisors for the EWRN operated and maintained by UW. Funding ended for BWIP in December 1988; the seismic program (including the UW contract) was transferred to the WHC Environmental Division. Maintenance 
responsibilities for the EWRN also were assigned to WHC, who made major upgrades to EWRN sites. Effective October 1, 1996, all seismic assessment activities were transferred to the Pacific Northwest National Laboratory (PNNL). ${ }^{1}$

The Hanford SMA network was constructed during 1997, becoming operational in May 1997. It was shut down in FY 1998 due to lack of funding but became operational again in FY 1999 and has operated continuously since that time.

\subsection{Documentation and Reports}

The HSAP issues quarterly reports of local activity, an annual catalog of earthquake activity in southeastern Washington, and special-interest bulletins on local seismic events. This includes information and special reports as requested by DOE and Hanford Site contractors. Earthquake information provided in these reports is subject to revision as new information becomes available. In addition, an archive of all seismic data from the HSAP is maintained by PNNL on computer servers.

\footnotetext{
${ }^{1}$ Pacific Northwest National Laboratory is operated by Battelle for the U.S. Department of Energy under Contract DE-AC05-76RL01830.
} 


\subsection{Network Operations}

\subsection{Seismometer Stations}

The seismic network consists of two types of earthquake sensors—seismometers and strong motion accelerometers (SMAs). Seismometers are designed primarily to detect micro earthquakes near Hanford recording seismograms that are used to determine the magnitudes and locations of seismic events. SMA stations are designed to measure ground motion and are discussed in Section 2.2.

The HSN and the EWRN consist of 44 seismometer stations. This includes three recently acquired Transportable Array (TA) stations located at Cold Creek (CCRK), Didier Farms (DDRF), and Phinney Hill (PHIN). The TA stations are tri-axial, broad-band seismometers with full digital telemetry capabilities. Most stations reside in remote locations and require solar panels and batteries for power. The HSN includes 26 stations (Table 2.1 and Figure 2.1), and the EWRN consists of 39 stations (Table 2.2 and Figure 2.2). Twenty-one stations are shared by both networks. Note that the Bickelton (BLT) and Phinney Hill (PHIN) stations are shown on Figure 2.2.

The EWRN is used by the HSAP for two major reasons. A large earthquake located in the Pacific Northwest outside of Hanford could produce significant ground motion and damage at the Hanford Site. For example, the magnitude 7.0 event that occurred in 1872 near Chelan/Entiat or other events located in the region (e.g., eastern Cascade mountain range) could have such an effect. The EWRN would provide valuable information to help determine the impacts of such an event. Additionally, the characterization of seismicity throughout the surrounding areas, as required for the Probabilistic Seismic Hazard Analysis, supports facility safety assessments at the Hanford Site. Both the HSN and the EWRN are fully integrated within the Pacific Northwest Seismic Network managed by the University of Washington. 
Table 2.1. Seismometer Stations in the Hanford Seismic Network

\begin{tabular}{|c|c|c|c|c|}
\hline Station $^{(a)}$ & $\begin{array}{c}\text { Latitude } \\
\text { Deg. Min. N }\end{array}$ & $\begin{array}{c}\text { Longitude } \\
\text { Deg. Min. W }\end{array}$ & Elevation (m) & Station Name \\
\hline BEN & $46 \mathrm{~N} 31.13$ & 119W43.02 & 340 & Benson Ranch \\
\hline BLT & $45 N 54.91$ & 120W10.55 & 659 & Bicklelton \\
\hline BRV & $46 N 29.12$ & 119W59.47 & 920 & Black Rock Valley \\
\hline BVW & 46N48.66 & 119W52.99 & 670 & Beverly \\
\hline CRF & $46 N 49.50$ & 119W23.22 & 189 & Corfu \\
\hline ET3 & 46N34.64 & 118W56.25 & 286 & Eltopia Three \\
\hline $\mathrm{CCRK}^{(\mathrm{b})}$ & $46 N 55.85$ & 119W85.49 & 560 & Cold Creek \\
\hline $\mathrm{DDRF}^{(\mathrm{b})}$ & $46 N 49.12$ & 119W05.96 & 270 & Didier Farms \\
\hline FHE $^{(\mathrm{b})}$ & 46N57.11 & 119W29.82 & 455 & Frenchman Hills East \\
\hline $\mathrm{PHIN}^{(\mathrm{b})}$ & 45N89.52 & 119W92.78 & 270 & Phinney Hill \\
\hline $\mathrm{GBB}^{(\mathrm{b})}$ & $46 N 36.49$ & 119W37.62 & 177 & Gable Butte \\
\hline GBL & 46N35.92 & 119W27.58 & 330 & Gable Mountain \\
\hline $\mathrm{H} 2 \mathrm{O}$ & $46 N 23.75$ & 119W25.38 & 158 & Water \\
\hline LOC & 46N43.02 & 119W25.85 & 210 & Locke Island \\
\hline MDW & $46 N 36.79$ & 119W45.66 & 330 & Midway \\
\hline MJ2 & $46 N 33.45$ & 119W21.54 & 146 & May Junction Two \\
\hline OT3 & $46 \mathrm{~N} 40.14$ & 119W13.98 & 322 & Othello Three \\
\hline PRO & $46 \mathrm{~N} 12.73$ & 119W41.15 & 550 & Prosser \\
\hline RED & 46N17.92 & 119W26.30 & 366 & Red Mountain \\
\hline RSW & $46 \mathrm{~N} 23.67$ & 119W35.48 & 1,045 & Rattlesnake Mountain \\
\hline SNI & $46 N 27.85$ & 119W39.60 & 312 & Snively Ranch \\
\hline VT2 & $46 N 58.04$ & 119W58.95 & 387 & Vantage Two \\
\hline WA2 & $46 N 45.32$ & 119W33.94 & 244 & Wahluke Slope \\
\hline WIW & $46 N 25.76$ & 119W17.26 & 128 & Wooded Island \\
\hline WRD & $46 N 58.20$ & 119W08.69 & 375 & Warden \\
\hline YPT & 46N02.93 & 118W57.73 & 325 & Yellepit \\
\hline \multicolumn{5}{|c|}{$\begin{array}{l}\text { (a) The first column is the alphanumeric seismic station designator. The latitude and longitude, elevation above sea level in } \\
\text { meters, and the full station name follow this. The locations of the stations all are in Washington; locations were derived } \\
\text { from the Global Positioning System (GPS). } \\
\text { (b) Three-component station. }\end{array}$} \\
\hline
\end{tabular}




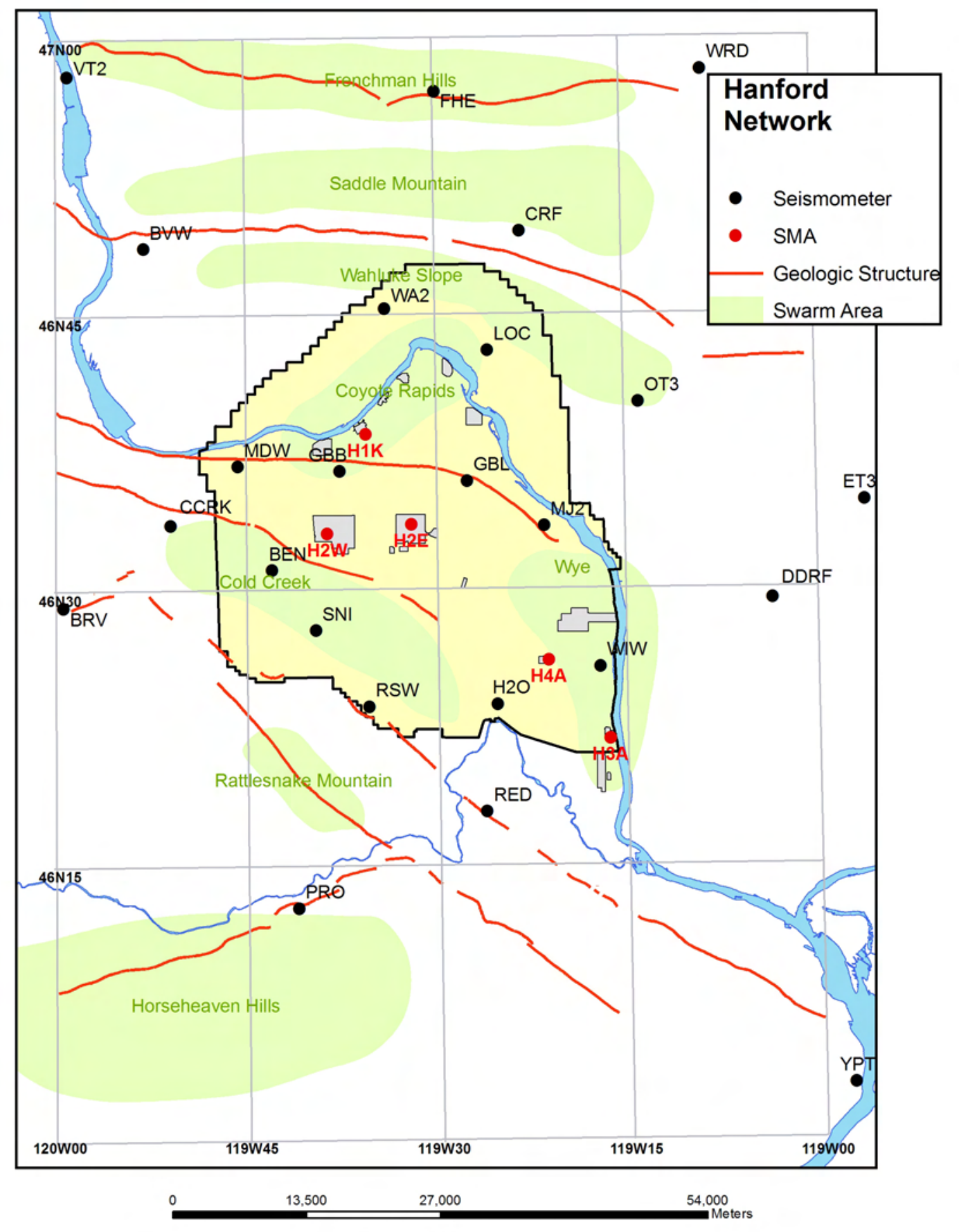

Figure 2.1. Seismometer and Strong Motion Accelerometer Stations in the Hanford Seismic Network 
Table 2.2. Seismometer Stations in the Eastern Washington Regional Network

\begin{tabular}{|c|c|c|c|c|}
\hline Station $^{(\mathrm{a})}$ & $\begin{array}{c}\text { Latitude } \\
\text { Deg. Min. N. }\end{array}$ & $\begin{array}{c}\text { Longitude } \\
\text { Deg. Min. W. }\end{array}$ & Elevation (m) & Station Name \\
\hline BLT & $45 N 54.91$ & 120W10.55 & 659 & Bickleton \\
\hline BRV & $46 N 29.12$ & 119W59.47 & 920 & Black Rock Valley \\
\hline BVW & 46N48.66 & 119W52.99 & 670 & Beverly \\
\hline CBS & $47 \mathrm{~N} 48.26$ & 120W02.50 & 1,067 & Chelan Butte South \\
\hline CRF & $46 N 49.50$ & 119W23.22 & 189 & Corfu \\
\hline DPW & 47N52.25 & 118W12.17 & 892 & Davenport \\
\hline DY2 & 47N59.11 & 119W46.28 & 890 & Dyer Hill Two \\
\hline ELL & 46N54.58 & 120W33.98 & 789 & Ellensburg \\
\hline EPH & 47N21.38 & 119W35.76 & 661 & Ephrata \\
\hline ET3 & 46N34.64 & 118W56.25 & 286 & Eltopia Three \\
\hline ETW & 47N36.26 & 120W19.94 & 1,477 & Entiat \\
\hline $\mathrm{CCRK}^{(\mathrm{b})}$ & $46 N 55.85$ & 119W85.49 & 560 & Cold Creek \\
\hline $\mathrm{DDRF}^{(\mathrm{b})}$ & $46 \mathrm{~N} 49.12$ & 119W05.96 & 270 & Didier Farms \\
\hline $\mathrm{FHE}^{(\mathrm{b})}$ & 46N57.11 & 119W29.82 & 455 & Frenchman Hills East \\
\hline $\mathrm{PHIN}^{(\mathrm{b})}$ & 45N89.52 & 119W92.78 & 270 & Phinney Hill \\
\hline GBL & $46 N 35.92$ & 119W27.58 & 330 & Gable Mountain \\
\hline LNO & $45 N 52.31$ & 118W17.11 & 771 & Lincton Mountain Oregon \\
\hline LOC & $46 \mathrm{~N} 43.02$ & 119W25.85 & 210 & Locke Island \\
\hline MDW & 46 N36.79 & 119W45.66 & 330 & Midway \\
\hline MJ2 & 46 N33.45 & 119W21.54 & 146 & May Junction Two \\
\hline MOX & 46 N34.64 & 120W17.89 & 501 & Moxee City \\
\hline NAC & $46 N 43.99$ & 120W49.42 & 728 & Naches \\
\hline NEL & $48 N 04.21$ & 120W20.41 & 1,500 & Nelson Butte \\
\hline OD2 & 47N23.26 & 118W42.58 & 553 & Odessa Two \\
\hline OT3 & $46 \mathrm{~N} 40.14$ & 119W13.98 & 322 & Othello Three \\
\hline PAT2 & 45N53.03 & 119W45.40 & 259 & Paterson Two \\
\hline PRO & 46N12.73 & 119W41.15 & 550 & Prosser \\
\hline RSW & 46N23.67 & 119W35.48 & 1,045 & Rattlesnake Mountain \\
\hline SAW & $47 N 42.10$ & 119W24.03 & 701 & St. Andrews \\
\hline TBM & $47 \mathrm{~N} 10.20$ & 120W35.88 & 1,006 & Table Mountain \\
\hline TRW & 46N17.32 & 120W32.31 & 723 & Toppenish Ridge \\
\hline TWW & 47N08.29 & 120W52.10 & 1,027 & Teanaway \\
\hline VT2 & $46 N 58.04$ & 119W58.95 & 387 & Vantage Two \\
\hline WA2 & $46 N 45.32$ & 119W33.94 & 244 & Wahluke Slope Two \\
\hline WAT & 47N41.92 & 119W57.24 & 821 & Waterville \\
\hline WIW & $46 \mathrm{~N} 25.76$ & 119W17.26 & 128 & Wooded Island \\
\hline WRD & $46 N 58.20$ & 119W08.69 & 375 & Warden \\
\hline YA2 & $46 N 31.60$ & 120W31.80 & 652 & Yakima Two \\
\hline YPT & $46 \mathrm{~N} 02.93$ & 118W57.73 & 325 & Yellepit \\
\hline \multicolumn{5}{|c|}{$\begin{array}{l}\text { (a) The first column is the alphanumeric seismic station designator. The latitude and longitude, elevation above sea level in } \\
\text { meters, and the full station name follow this. The locations of the stations all are in Washington unless otherwise } \\
\text { indicated; locations were determined from the Global Positioning System (GPS). } \\
\text { (b) Three-component station. }\end{array}$} \\
\hline
\end{tabular}




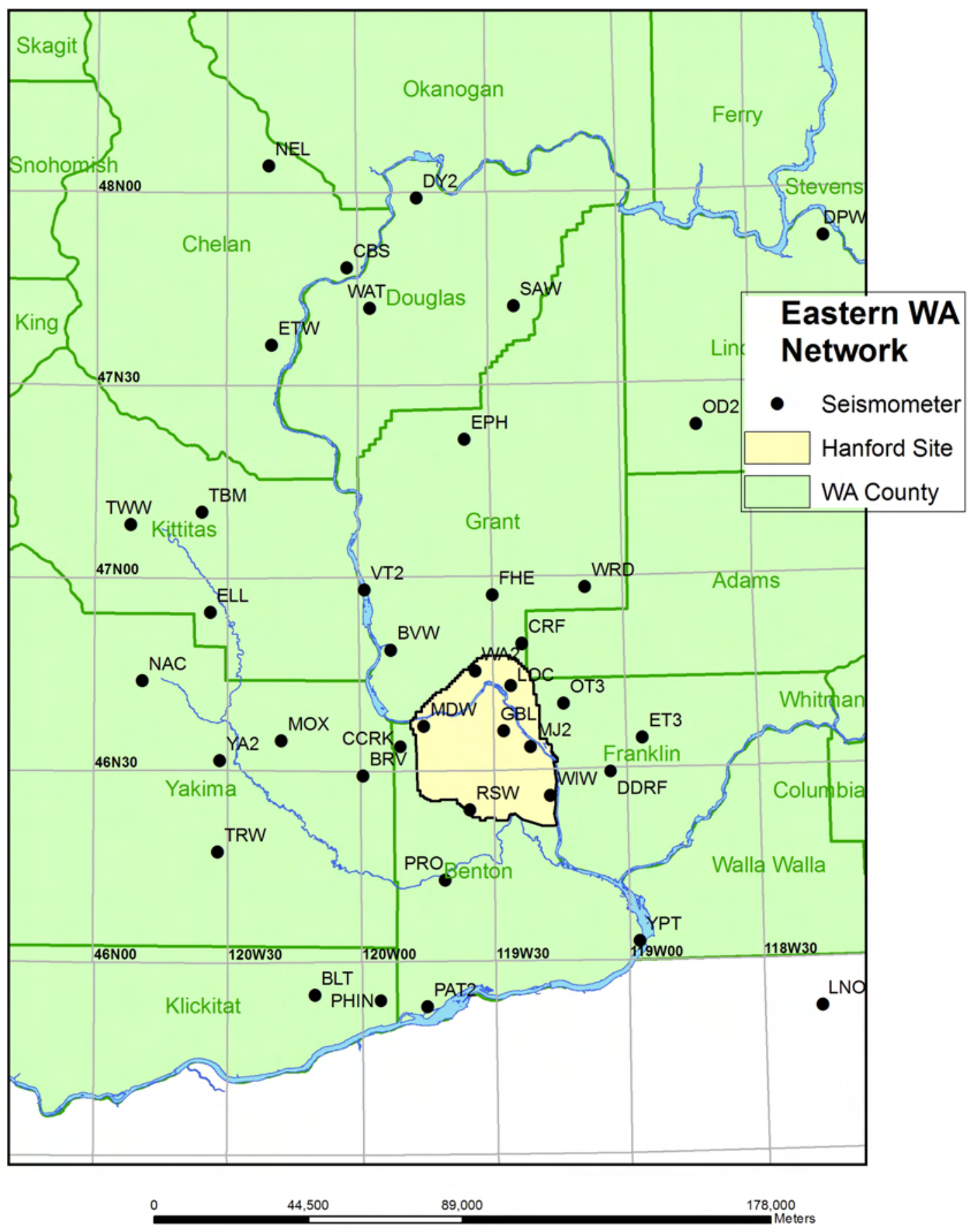

Figure 2.2. Seismometer Stations in the Eastern Washington Regional Network 
The HSN and EWRN networks have 54 combined data channels because the three-component sites (Gable Butte, Frenchman Hills East, Cold Creek, Didier Farms, and Phinney Hill) require 4 additional data channels per station. The tri-axial stations record motion in the vertical, north-south horizontal, and east-west horizontal directions. The other 39 stations are single vertical component seismometers. Fifteen radio telemetry relay sites are used by both networks to continuously transmit seismogram data to the Seismic Assessment Laboratory in the Sigma V building, Richland, Washington, for processing and archiving.

\subsubsection{Station Maintenance}

The fourth quarter of FY 2008 was a typical period of warm sunny days with excellent sunlight. The remote location of the seismic monitoring sites (Figure 2.3) necessitates total dependency on solar power generation. Generally, the long summer days are conducive to optimal solar panel energy production and peak battery recharge. Site maintenance was minimal.

Continued efforts were made to improve the data transmission of the three newly acquired Transportable Array stations located at Cold Creek (CCRK), Didier Farms (DDRF), and Phinney Hill (PHIN). This involved reorienting the site antennas as the cell phone carriers improve their local area coverage with new cell towers and hardware upgrades. New Raven X modems were installed to replace the older Raven Edge equipment. This required a change in modem settings and vault cable design to accommodate the faster Ethernet function.

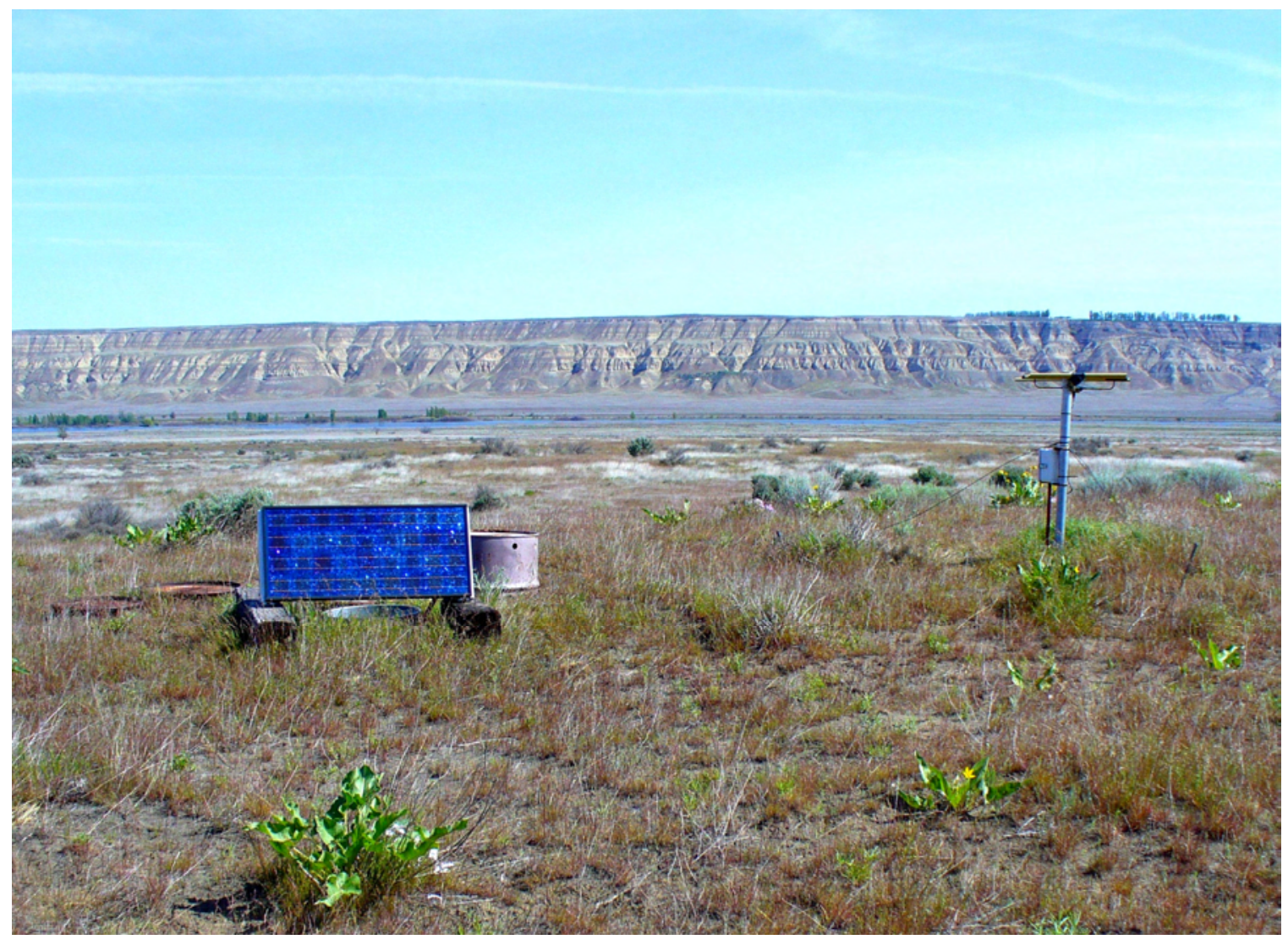

Figure 2.3. White Bluffs behind May Junction site (MJ2) 
During FY 2007, the HSAP began upgrading the Hanford seismometer network with the ultimate goal of replacing analog radio telemetry with digital, Internet-based telemetry. The upgrade will help eliminate the reliance on aging radio receiving and multiplexing equipment currently located in the Seismic Assessment Laboratory in the Sigma V building. The first upgrade is planned for the Gable Butte seismometer station (GBB) to be equipped with tri-axial broad-band seismometers with built-in digitizing and telemetry equipment.

Work progressed on upgrading GBB. Communications were established that allowed data transmissions between the tri-axial, broad-band seismometers, the Quanterra Q330 data recorder, and the internet. Earthworm version 7.2 was installed on PNNL servers so that digital data transmissions are received at the HSAP laboratory. The GBB equipment is scheduled to be installed in the field in the first quarter of FY 2009.

\subsubsection{Data Acquisition}

The signals from the seismometer stations are monitored for changes in signal amplitude that are expected from earthquakes. The seismic network is subdivided into spatial groupings of stations that are monitored for nearly simultaneous amplitude changes, resulting in triggering a permanent recording of the events. The groupings and associated weighting schemes are designed to allow very small seismic events to be recorded and to minimize false triggers. Events are classified as local (south-central Washington near the Hanford Site), regional (western United States and Canada), and teleseisms (from farther distances around the world). Local and regional events are usually earthquakes, but quarry and mining explosions also are recorded. Quarry and mining explosions usually can be identified from wave characteristics and the time of occurrence and may be confirmed with local government agencies and industries. Frequently, military exercises at the U.S. Army Yakima Training Center produce a series of acoustic shocks that trigger the recording system. Sonic booms and thunder also produce acoustic signals that may trigger the recording system.

The HSAP uses Earthworm, a PC-based system developed by the USGS and used by the Pacific Northwest Seismic Network at the UW, to record triggered events. One Earthworm system has been in continuous operation since January 6, 1999. A second system was installed in mid-March 1999. Both systems have been running in parallel since that time, with periodic hardware and software upgrades performed. Seismogram data from triggered events are collected on a SUN workstation (Sun Microsystems, Santa Clara, California) for assessment by HSAP staff. This information is evaluated to determine if the event is "false" (for example, due to a sonic boom) or is an earthquake or ground-surface or underground blast. Earthquake events are evaluated to determine epicenter locations, focal depths, and magnitudes (Section 4).

Although the two Earthworm systems are practically identical, slight differences in the trigger algorithms, combined with the granularity of the signal-measurement time windows, sometimes result in triggered events from one Earthworm system but not the other. These different or exclusive events are generally "false" triggers resulting from acoustical sources and not earthquakes or quarry blasts. Sometimes these exclusive events correspond to barely detectable, distant regional, or teleseismic earthquakes. 


\subsection{Strong Motion Accelerometer Stations}

\subsubsection{Location}

The Hanford SMA network consists of five free-field SMA stations (see Figure 2.1; Table 2.3). SMAs are located in the 200 East and 200 West Areas, in the 100-K Area adjacent to the K Basins, in the 400 Area near the former Fast Flux Test Facility, and at the south end of the 300 Area.

The locations of SMA stations were chosen based on two criteria: 1) density of workers and 2) siting of hazardous facilities (Moore and Reidel 1996). The 200 East and 200 West Areas contain single-shell and double-shell tanks in which high-level radioactive wastes from past processing of fuel rods are stored. In addition, the Canister Storage Facility (holding encapsulated spent fuel rods) and the new Waste Treatment and Immobilization Plant being constructed are both located in the 200 East Area. The 100-K Area contains the K Basins, where spent fuel rods from the $\mathrm{N}$ Reactor were stored prior to encapsulation.

Table 2.3. Free-Field Strong Motion Accelerometer Sites

\begin{tabular}{|c|c|c|c|}
\hline Site & Site ID & Location & $\begin{array}{l}\text { Latitude } \\
\text { Longitude } \\
\text { Elevation }\end{array}$ \\
\hline $100 \mathrm{~K}$ Area & $\mathrm{H} 1 \mathrm{~K}$ & South of K Basins outside 100 Area fence lines & $\begin{array}{l}46^{\circ} 38.51^{\prime} \\
119^{\circ} 35.53 \\
152 \mathrm{~m}\end{array}$ \\
\hline 200 East Area & $\mathrm{H} 2 \mathrm{E}$ & $\begin{array}{l}\text { East of B Plant; northwest of Waste Treatment and } \\
\text { Immobilization Plant; north of 7th Street and east of } \\
\text { Baltimore Avenue }\end{array}$ & $\begin{array}{l}46^{\circ} 33.58^{\prime} \\
119^{\circ} 32.00^{\prime} \\
210 \mathrm{~m}\end{array}$ \\
\hline 200 West Area & $\mathrm{H} 2 \mathrm{~W}$ & $\begin{array}{l}\text { West of Plutonium Finishing Plant (PFP) and } 200 \text { West Area } \\
\text { tree barrier }\end{array}$ & $\begin{array}{l}46^{\circ} 33.11^{\prime} \\
119^{\circ} 38.64^{\prime} \\
201 \mathrm{~m}\end{array}$ \\
\hline 300 Area & H3A & $\begin{array}{l}\text { South end of } 300 \text { Area inside fence lines (NE 1/4, SW 1/4, } \\
\text { Sec. 11, T10N, R28E) }\end{array}$ & $\begin{array}{l}46^{\circ} 21.83^{\prime} \\
119^{\circ} 16.55^{\prime} \\
119 \mathrm{~m}\end{array}$ \\
\hline 400 Area & $\mathrm{H} 4 \mathrm{~A}$ & $\begin{array}{l}500 \mathrm{ft} \text { from fence line on east side of facility and north of } \\
\text { parking area) }\end{array}$ & $\begin{array}{l}46^{\circ} 26.13^{\prime} \\
119^{\circ} 21.30^{\prime} \\
171 \mathrm{~m}\end{array}$ \\
\hline
\end{tabular}

The Cold Vacuum Drying Facility, also located in the 100-K Area, is used to encapsulate spent fuel rods from the K Basins prior to shipment to the Canister Storage Building in the 200 East Area. The 400 Area is the site of construction activities.

\subsubsection{Station Design}

All free-field SMA stations consist of a four-panel solar array and two 30-gal galvanized drums that contain equipment. Each panel has a maximum 42-W output. The two 30-gal drums are set in the ground such that the base of each drum is about $1 \mathrm{~m}$ below the ground surface. One drum houses only the SMA; the other drum, which is connected via a sealed conduit to the SMA drum, contains the batteries. Data communication is provided by a General Packet Radio Service (GPRS) system, a continuous radio datalink to an Internet service provider. The GPRS system along with the solar power regulator is housed in a 
small enclosure mounted at the rear of the solar array. The enclosure serves as a junction box for all cabling between equipment inside and outside the drums through conduit. The antenna for the GPRS is mounted on top of the enclosure. The enclosure permits quick access to check battery conditions and a connection directly to the RS-232 port of the SMA without removing the drum lids.

The SMA stations are three-component units consisting of vertical, north-south horizontal, and eastwest horizontal seismometers manufactured by Kinemetrics, Inc., Pasadena, California, and known as the ETNA system (specifications summarized in Table 2.4). Each ETNA unit contains a digital recorder, a data storage unit, and a Global Positioning System (GPS) receiver (Figure 2.4). These components are housed in a watertight box.

Table 2.4. Instrument Parameters for the Kinemetrics ETNA System in the Hanford SMA Network

\begin{tabular}{|c|c|}
\hline Parameter & Value or Range \\
\hline \multicolumn{2}{|r|}{ Sensor } \\
\hline Type & Triaxial EpiSensor Accelerometer \\
\hline Full-scale & $\pm 2 g^{(a)}$ \\
\hline Frequency range & $0-80 \mathrm{~Hz}$ \\
\hline Damping & Approximately 70\% critical $^{(\mathrm{a})}$ \\
\hline \multicolumn{2}{|r|}{ Data Acquisition } \\
\hline Number of channels & 3 \\
\hline Sample rate & 200 samples/sec \\
\hline Resolution & 18 bits \\
\hline Digital output & Real-time, RS-232 output stream \\
\hline \multicolumn{2}{|r|}{ Seismic Trigger } \\
\hline Filter & $0.1-12.5 \mathrm{~Hz}$ \\
\hline Trigger level & $0.02 \% \mathrm{~g}^{(\mathrm{b})}$ \\
\hline Alarm (call-out) threshold & Not activated \\
\hline Pre-event memory & $10 \mathrm{~s}$ \\
\hline Post-event time & $40 \mathrm{~s}$ \\
\hline \multicolumn{2}{|c|}{$\begin{array}{l}\text { (a) Setting is dependent on instrument calibration. } \\
\text { (b) See Section 2.2.4 for discussion of trigger thresholds. }\end{array}$} \\
\hline
\end{tabular}

The GPRS system provides the Internet address connection to access the system. Stations can be monitored from any computer with appropriate access, and data can be downloaded to a dedicated computer in the Seismic Assessment Laboratory. The data also can be downloaded directly at each site via a built-in cable connection at the enclosure in case of communication failure.

The GPS receiver is used principally to access the National Bureau of Standards timing system. The GPS receiver antenna is mounted on the enclosure at the rear of the solar array. The GPS receiver is activated internally approximately every $4 \mathrm{hr}$ and checks the "location of the instrument" and the time. 
Any differences between the internal clock and the GPS time are recorded by the SMA. Any corrections to the internal timing are made automatically. Typically, the greatest correction recorded is approximately 4 milliseconds (ms).

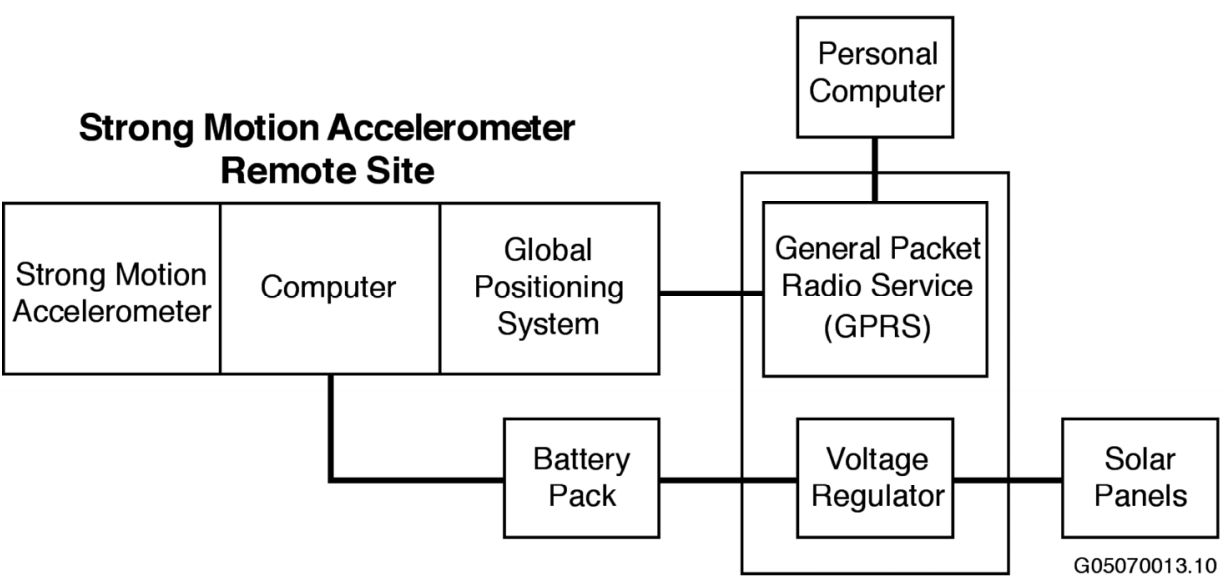

Figure 2.4. Schematic Diagram of a Strong Motion Accelerometer Installation

\subsubsection{Strong Motion Accelerometer Operations Center}

The combined operations, data recording, data interpretation, and maintenance facility is located in the Sigma V Building and is operated by the HSAP.

\subsubsection{Strong Motion Operational Characteristics}

Signals from the three accelerometer channels use an 18-bit digitizer with data temporarily stored in a memory buffer. The digital sampling rate is 200 samples/s. The three channels are monitored for signals that exceed a programmable trigger threshold. When one accelerometer channel is triggered, the other channels automatically record. The nominal threshold used from 1998 to 2006 was $0.1 \% \mathrm{~g}(0.05 \%$ of the full-scale range of $2.0 \mathrm{~g}$; $\mathrm{g}$ is the acceleration of gravity, $9.8 \mathrm{~m} / \mathrm{s}^{2}$ or $32 \mathrm{ft} / \mathrm{s}^{2}$ ). Threshold trigger levels are set to trigger infrequently on noise sources (e.g., vehicles, sonic booms) near each site. In 2006, larger data storage capacities were installed that allowed the trigger thresholds to be reduced to $0.02 \% \mathrm{~g}$ (see Section 6). This permits the recording of ground motion data for smaller, non-damaging earthquakes that can be useful in estimating impacts of larger earthquakes. It also helps confirm the correct operation of the instruments by analyzing the smaller-amplitude triggers.

When one of the accelerometer channels exceeds the trigger threshold, the recorders save information within the data buffers. Data recording begins $10 \mathrm{~s}$ before the actual trigger time, continues until the trigger threshold is no longer exceeded, and ends with an additional $40 \mathrm{~s}$ of data. The saved files created by a triggered event are stored on memory cards to be retrieved and examined by HSAP staff. 


\subsection{Geology and Tectonic Analysis}

The Hanford Site lies within the Columbia Basin, an intermontane basin between the Cascade Range and the Rocky Mountains filled with Cenozoic volcanic rocks and sediments. This basin forms the northern part of the Columbia Plateau physiographic province (Fenneman 1931) and the Columbia River flood-basalt province (Reidel et al. 1989). In the central and western parts of the Columbia Basin, the Columbia River Basalt Group (CRBG) overlies Tertiary continental sedimentary rocks and is overlain by late Tertiary and Quaternary fluvial and glaciofluvial deposits (Campbell 1989; Reidel et al. 1989, 1994; DOE 1988). In the eastern part, a thin $(<100-\mathrm{m})$ sedimentary unit separates the basalt and underling crystalline basement, and a thin $(<10-\mathrm{m})$ veneer of eolian sediments overlies the basalt (Reidel et al. 1989, 1994).

The Columbia Basin has two structural subdivisions or subprovinces—the Yakima Fold Belt and the Palouse Slope. The Yakima Fold Belt includes the western and central parts of the Columbia Basin and is a series of anticlinal ridges and synclinal valleys with major thrust faults typically along the northern flanks (Figure 3.1) (Reidel and Fecht 1994a, 1994b). The Palouse Slope is the eastern part of the basin and is less deformed than the Yakima Fold Belt, with only a few faults and low-amplitude long-wavelength folds on an otherwise gently westward dipping paleoslope. Figure 3.2 shows north-south (B-B') and east-west (A-A') cross sections through the Columbia Basin based on surface mapping (Reidel and Fecht 1994a, 1994b), deep boreholes (Reidel et al. 1994), geophysical data (Rohay et al. 1985; DOE 1988), and magnetotelluric data obtained as part of BWIP (DOE 1988).

\subsection{Earthquake Stratigraphy}

Seismic studies at the Hanford Site have shown that the earthquake activity is related to crustal stratigraphy (large groupings of rock types) (Rohay et al. 1985; DOE 1988). The main geologic units important to earthquakes at the Hanford Site and the surrounding area are

- the Miocene CRBG

- pre-basalt sediments of Paleocene, Eocene, Oligocene, and Early Miocene age

- the crystalline basement composed of Precambrian and Paleozoic craton/continental margin

- Mesozoic accreted terranes.

\subsection{Geologic Structure Beneath the Monitored Area}

Between the late 1950s and the mid 1980s, deep boreholes were drilled for hydrocarbon exploration in the Columbia Basin. These boreholes provided accurate measurements of the physical properties of the CRBG and the pre-basalt sediments (Reidel et al. 1989, 1994), but the thickness of the pre-basalt sediments and nature of the crystalline basement are still poorly understood. Table 3.1, derived from Reidel et al. (1994), was developed for the geologic interpretation in this report. The thicknesses of these units are variable across the monitored area. Table 3.1 summarizes the approximate thickness at the borders of the monitored area. 


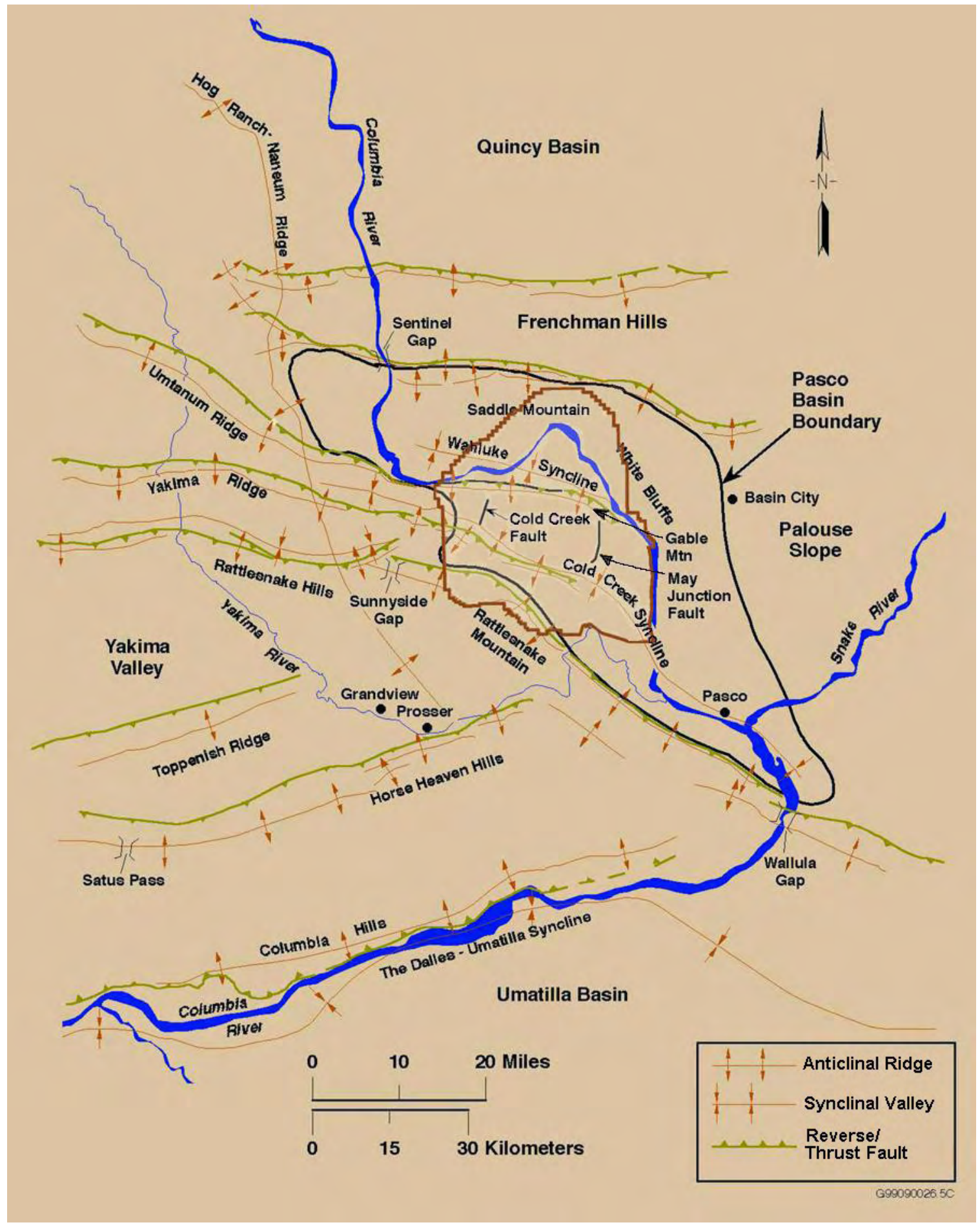

Figure 3.1. Physical and Structural Geology of the Hanford Site, Washington 


\section{Yakima Fold Belt}

Palouse Slope

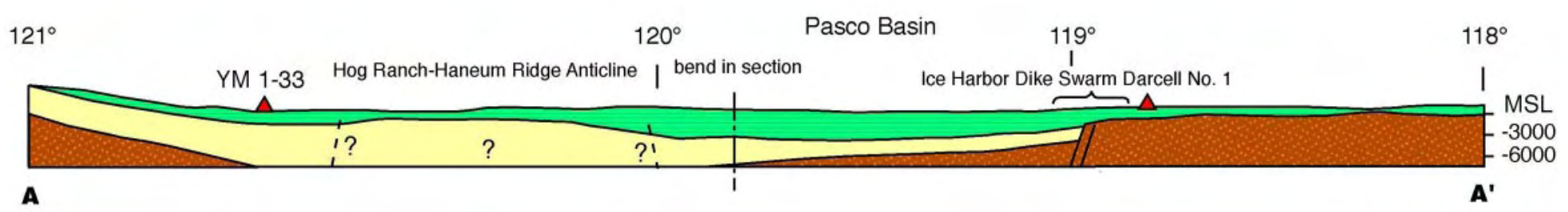

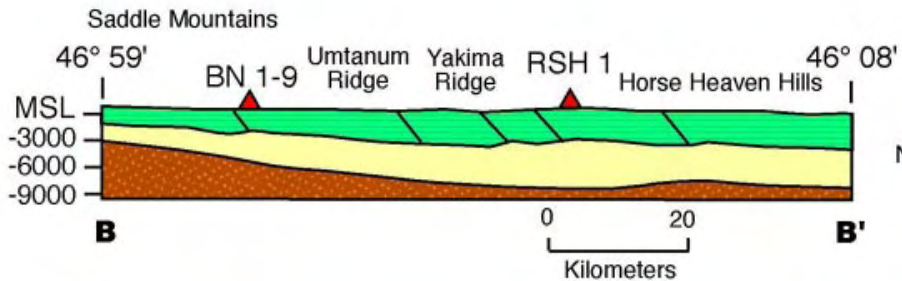

$\Delta$ Hydrocarbon exploration borehole
Columbia River Basalt Group
NO VERTICAL EXAGGERATION

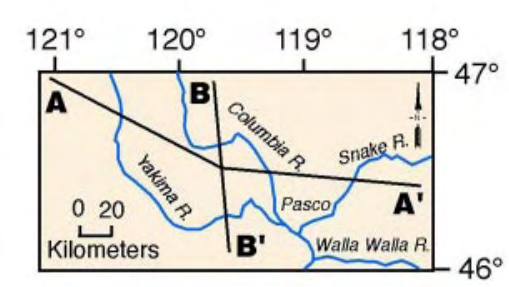

Basement rock

G01010082.2

Figure 3.2. Geologic Cross Sections through the Columbia Basin (Reidel et al. 1994) 
Table 3.1. Thicknesses of Stratigraphic Units in the Monitoring Area (from Reidel et al. 1994)

\begin{tabular}{||l|c|c|c|c||}
\hline \multicolumn{1}{|c|}{ Stratigraphy } & North & South & East & West \\
\hline \hline Columbia River Basalt Group (includes suprabasalt sediments) & $3.0 \mathrm{~km}$ & $4.5 \mathrm{~km}$ & $2.2 \mathrm{~km}$ & $4.2 \mathrm{~km}$ \\
\hline Pre-basalt sediments & $3.0 \mathrm{~km}$ & $>4.5 \mathrm{~km}$ & 0 & $>6.0 \mathrm{~km}$ \\
\hline
\end{tabular}

The thickness of the basalt and the pre-basalt sediments varies as a result of different tectonic environments. The western edge of the North American craton (late Precambrian/Paleozoic continental margin and Precambrian craton) is located in the eastern portion of the monitored area (Reidel et al. 1994). The stratigraphy on the craton consists of CRBG overlying crystalline basement; the crystalline basement is continental crustal rock that underlies much of the western North America. The stratigraphy west of the craton consists of 4 to $5 \mathrm{~km}$ of CRBG overlying up to $6 \mathrm{~km}$ of pre-basalt sediments. This in turn overlies accreted terranes of Mesozoic age. The area west of the craton was subsiding during the Eocene and Oligocene, accumulating great thickness of pre-CRBG sediments. Continued subsidence in this area during the Miocene resulted in thicker CRBG compared to that on the craton. Subsidence continues today but at a greatly reduced rate (Reidel et al. 1994).

\subsection{Tectonic Pattern}

Studies have concluded that earthquakes can occur in the following six different tectonic environments (earthquake sources) at the Hanford Site (Geomatrix 1996):

- Major Geologic Structures. Reverse/thrust faults in the CRBG associated with major anticlinal ridges such as Rattlesnake Mountain, Yakima Ridge, and Umtanum Ridge could produce some of the largest earthquakes.

- Secondary Faults. These faults are typically smaller (1 to $20 \mathrm{~km}$ in length) than the main reverse/ thrust faults that occur along the major anticlinal ridges (up to $100 \mathrm{~km}$ in length). Secondary faults can be segment boundaries (tear faults) and small faults of any orientation that formed along with the main structure.

- Swarm Areas. Small geographic areas not known to contain any geologic structures produce clusters of events (swarms), usually located in synclinal valleys. These clusters consist of a series of small shocks with no outstanding principal event. Swarms occur over a period of days or months, and the events may number into the hundreds and then quit, only to start again at a later date. This differs from the sequence of foreshocks, mainshock, and trailing-off aftershocks that have the same epicenter or are associated with the same fault system. In the past, swarms were thought to occur only in the CRBG. Most swarm areas are in the basalt, but swarm events also appear to occur in all geologic layers. However, typically a swarm event at a specific time is usually restricted to one layer. Seven earthquake swarm areas are recognized in the HSN area, but this list will be updated as new swarm areas develop. The Saddle Mountains, Wooded Island, Wahluke, Coyote Rapids, and Horse Heaven Hills swarm areas are typically active at one time or another during the year (see Figure 5.2 for a map of these swarm areas). The other earthquake swarm areas are active less frequently.

- Entire Columbia Basin. The entire basin, including the Hanford Site, could produce a "floating” earthquake. A floating earthquake is one that, for seismic design purposes, can happen anywhere in a tectonic province and is not associated with any known geologic structure. Seismic interpretation classifies it as a random event for purposes of seismic design and vibratory ground motion studies. 
- Basement Source Structures. Studies (Geomatrix 1996) suggest that major earthquakes can originate in tectonic structures in the crystalline basement. Because little is known about geologic structures in the crystalline basement beneath the Hanford Site, earthquakes cannot be directly tied to a mapped fault. Earthquakes occurring in the crystalline basement without known sources are treated as random events.

- Cascadia Subduction Zone. This source has been postulated to be capable of producing a magnitude 9 earthquake. Because this source is along the western boundary of Washington State and outside the HSN, the Cascadia subduction zone is not an earthquake source that is monitored at the Hanford Site, so subduction zone earthquakes are not reported here. Because any earthquake along the Cascadia subduction zone can have a significant impact on the Hanford Site or can be felt like the February 2001 Nisqually earthquake, UW monitors and reports on this earthquake source for the DOE. Ground motion from any moderate or larger Cascadia subduction zone earthquake is detected by Hanford SMAs and reported (see Section 5). 


\subsection{Earthquake Catalog Description}

An interactive program called XPED, developed at the University of Washington, is used to determine earthquake locations and magnitudes. This program reads seismogram data recorded by the Earthworm system and lets the user measure arrival times and durations from earthquakes. Arrival and duration times are used as input to the hypocenter routine within XPED to estimate locations and magnitudes of the seismic events. XPED results for local earthquakes (46-47 north latitude, $119-120^{\circ}$ west longitude) are reported in Table 4.1. Other seismic events located in southeastern Washington, the Pacific Northwest, or outside the region also are evaluated, with results stored on the computer system; these results are not reported in this document. These other results sometimes are used as a check to confirm that the HSN is functioning properly (e.g., quality checks on data recording).

\subsection{Coda-Length Magnitude}

Coda-length magnitude $\left(\mathrm{M}_{\mathrm{c}}\right)$, an estimate of local magnitude $\left(\mathrm{M}_{\mathrm{L}}\right)$ (Richter 1958), is calculated using a relationship developed for Washington State by Crosson (1972):

$$
\mathrm{M}_{\mathrm{c}}=2.82 \log (\mathrm{D})-2.46
$$

where $\mathrm{D}$ is the duration of the observed event. Many of the earthquakes have magnitude determinations that are very small $\left(\mathrm{M}_{\mathrm{c}}<0\right)$ and highly uncertain. In Section 4, we define earthquakes as "minor" with magnitudes $\left(\mathrm{M}_{\mathrm{c}}\right)$ smaller than 1.0. Coda-length magnitudes for events classified as explosions are not reported because they are biased by a prominent surface wave that extends the apparent duration in a way inconsistent with coda-length measurement.

\subsection{Velocity Model}

XPED uses the crustal velocity model for eastern Washington given in Table 4.2. The model does not include a surficial layer for the Hanford or Ringold formations because most seismometer stations are sited on basalt. The crustal velocity model extends $38 \mathrm{~km}$ deep (to the mantle) and consists of six layers, each with uniform seismic velocity. The crustal velocity model was developed using available geologic information and calibrated from seismic data recorded from accurately located earthquake and blast events in eastern Washington. Time corrections (delays) are incorporated into the velocity model to account for significant deviations in station elevations or stations situated on sedimentary layers. Station delays also are determined empirically from accurately located earthquakes and blast events in the region. 
Table 4.1. Local Seismic Data, October 1, 2007 - September 30, 2008

\begin{tabular}{|c|c|c|c|c|c|c|c|c|c|c|c|c|c|}
\hline Event ID & Type & Date & Time & Latitude & Longitude & Depth & Mag & NS/NP & Gap & Dmin & RMS & $\mathrm{Q}$ & Location \\
\hline 07100311561 & & 07/10/03 & $11: 56: 36.38$ & $46 N 18.41$ & 119W32.94 & 7.31 & 1.4 & $26 / 34$ & 77 & 9 & 0.15 & $\mathrm{AB}$ & $20 \mathrm{~km} \mathrm{~W}$ of Richland \\
\hline 07100311573 & & 07/10/03 & 11:57:59.95 & $46 N 18.44$ & 119W32.77 & 7.20 & 0.3 & $11 / 18$ & 169 & 9 & 0.05 & $\mathrm{AC}$ & 20 km W of Richland \\
\hline 07101900462 & & 07/10/19 & $00: 46: 45.49$ & $46 N 51.32$ & 119W37.16 & 16.46 & 0.5 & $21 / 26$ & 88 & 11 & 0.11 & AA & 24 km N of $100-\mathrm{K}$ Area \\
\hline 07102313040 & & $07 / 10 / 23$ & 13:04:27.13 & $46 N 43.37$ & 119W28.81 & 4.36 & -0.1 & $6 / 08$ & 161 & 3 & 0.09 & AC & $13 \mathrm{~km} \mathrm{NE}$ of $100-\mathrm{K}$ Area \\
\hline 07102620501 & & $07 / 10 / 26$ & 20:50:34.15 & $46 N 43.38$ & 119W29.81 & 2.44 & -0.7 & $5 / 10$ & 153 & 5 & 0.10 & $\mathrm{AD}$ & $12 \mathrm{~km} \mathrm{NE}$ of $100-\mathrm{K}$ Area \\
\hline 07110915255 & & 07/11/09 & $15: 26: 18.62$ & $46 N 38.81$ & 119W28.04 & 16.41 & 0.5 & $21 / 26$ & 47 & 5 & 0.12 & AA & $10 \mathrm{~km} \mathrm{E}$ of $100-\mathrm{K}$ Area \\
\hline 07111014464 & & 07/11/10 & $14: 47: 11.31$ & $46 N 28.40$ & 119W15.46 & 0.43 & -0.4 & $4 / 04$ & 244 & 5 & 0.02 & $\mathrm{AD}$ & $9 \mathrm{~km}$ ENE of 400 Area \\
\hline 07111812431 & & 07/11/18 & $12: 43: 31.85$ & 46 N20.24 & 119W40.52 & 7.89 & 0.1 & $7 / 10$ & 167 & 9 & 0.04 & $\mathrm{AC}$ & 16 km NNE of Prosser \\
\hline 07111813064 & & 07/11/18 & 13:07:08.23 & $46 N 20.28$ & 119W40.79 & 6.13 & 0.5 & $9 / 12$ & 166 & 9 & 0.07 & $\mathrm{AC}$ & $16 \mathrm{~km}$ NNE of Prosser \\
\hline 07111813072 & & 07/11/18 & 13:07:37.64 & $46 N 20.24$ & $119 W 40.47$ & 7.43 & -0.2 & $3 / 06$ & 303 & 9 & 0.03 & $\mathrm{AD}$ & 16 km NNE of Prosser \\
\hline 07111813135 & & 07/11/18 & 13:14:15.15 & $46 N 20.23$ & 119W40.72 & 5.49 & 0.1 & $8 / 11$ & 169 & 9 & 0.04 & AC & $16 \mathrm{~km}$ NNE of Prosser \\
\hline 07111900542 & & 07/11/19 & 00:54:48.71 & $46 N 20.27$ & 119W40.81 & 4.56 & 1.2 & $16 / 19$ & 122 & 9 & 0.08 & $\mathrm{AB}$ & 16 km NNE of Prosser \\
\hline 07111909522 & & 07/11/19 & 09:52:53.38 & $46 N 20.31$ & $119 W 40.73$ & 5.75 & 0.9 & $17 / 20$ & 122 & 9 & 0.11 & $\mathrm{AB}$ & $16 \mathrm{~km}$ NNE of Prosser \\
\hline 07111910122 & & 07/11/19 & $10: 12: 43.79$ & $46 N 20.30$ & $119 W 40.67$ & 6.13 & 0.3 & $7 / 10$ & 169 & 9 & 0.04 & $\mathrm{AC}$ & 16 km NNE of Prosser \\
\hline 07111919565 & & 07/11/19 & 19:57:16.99 & $46 N 20.29$ & 119W40.81 & 5.62 & 0.5 & $8 / 11$ & 170 & 9 & 0.06 & $\mathrm{AC}$ & $16 \mathrm{~km}$ NNE of Prosser \\
\hline 07112111375 & & $07 / 11 / 21$ & 11:38:15.28 & $46 N 20.22$ & 119W40.29 & 6.58 & 0.3 & $10 / 14$ & 162 & 8 & 0.07 & $\mathrm{AC}$ & $16 \mathrm{~km}$ NNE of Prosser \\
\hline 07112112022 & & $07 / 11 / 21$ & $12: 02: 49.56$ & $46 N 20.34$ & 119W40.66 & 5.45 & 0.1 & $9 / 12$ & 165 & 9 & 0.06 & AC & $16 \mathrm{~km}$ NNE of Prosser \\
\hline 07112112260 & & $07 / 11 / 21$ & $12: 26: 22.87$ & $46 N 20.90$ & 119W39.24 & 7.64 & -0.3 & $3 / 06$ & 295 & 7 & 0.02 & $\mathrm{AD}$ & 18 km NNE of Prosser \\
\hline 07112117554 & & $07 / 11 / 21$ & $17: 56: 10.16$ & $46 N 20.25$ & $119 W 40.67$ & 4.75 & 0.6 & $13 / 16$ & 165 & 9 & 0.06 & $\mathrm{AC}$ & $16 \mathrm{~km}$ NNE of Prosser \\
\hline 07112402092 & & $07 / 11 / 24$ & 02:09:51.48 & $46 N 20.25$ & 119W40.46 & 5.92 & 0.4 & $10 / 14$ & 164 & 8 & 0.05 & AC & 16 km NNE of Prosser \\
\hline 07112406452 & & $07 / 11 / 24$ & 06:45:47.19 & $46 N 13.74$ & 119W33.92 & 8.18 & 0.2 & $8 / 09$ & 206 & 9 & 0.06 & $\mathrm{AD}$ & $16 \mathrm{~km} \mathrm{E}$ of Prosser \\
\hline 07112407361 & & $07 / 11 / 24$ & 07:36:39.69 & $46 \mathrm{~N} 20.20$ & 119W40.03 & 6.46 & 0.3 & $11 / 14$ & 117 & 8 & 0.14 & $\mathrm{AB}$ & $16 \mathrm{~km}$ NNE of Prosser \\
\hline 07112408452 & & $07 / 11 / 24$ & 08:45:45.96 & $46 N 20.26$ & $119 W 40.74$ & 5.32 & 0.2 & $9 / 12$ & 166 & 9 & 0.07 & $\mathrm{AC}$ & $16 \mathrm{~km}$ NNE of Prosser \\
\hline 07112409163 & & $07 / 11 / 24$ & 09:16:59.48 & $46 N 20.35$ & 119W40.58 & 5.88 & 0.4 & $10 / 13$ & 165 & 8 & 0.05 & $\mathrm{AC}$ & 16 km NNE of Prosser \\
\hline 07112409190 & & $07 / 11 / 24$ & 09:19:00.34 & $46 N 20.29$ & 119W40.63 & 6.43 & 0.2 & $6 / 09$ & 182 & 9 & 0.07 & $\mathrm{AD}$ & $16 \mathrm{~km}$ NNE of Prosser \\
\hline 07112506091 & & $07 / 11 / 25$ & 06:09:35.85 & 46 N20.18 & 119W40.49 & 4.97 & 0.3 & $7 / 10$ & 164 & 9 & 0.07 & AC & 16 km NNE of Prosser \\
\hline 07112511584 & & $07 / 11 / 25$ & 11:59:11.97 & $46 N 20.40$ & 119W40.81 & 4.33 & 1.5 & $17 / 20$ & 122 & 9 & 0.08 & $\mathrm{AB}$ & $16 \mathrm{~km}$ NNE of Prosser \\
\hline 07112617244 & & $07 / 11 / 26$ & $17: 25: 06.24$ & $46 N 19.69$ & 119W41.72 & 3.45 & 0.6 & $7 / 11$ & 255 & 10 & 0.08 & $\mathrm{BD}$ & 15 km NNE of Prosser \\
\hline 07112801200 & & $07 / 11 / 28$ & 01:20:30.32 & $46 N 20.23$ & 119W40.61 & 5.50 & 0.7 & $11 / 15$ & 165 & 9 & 0.07 & $\mathrm{AC}$ & $16 \mathrm{~km}$ NNE of Prosser \\
\hline 07112810484 & & $07 / 11 / 28$ & 10:49:03.63 & $46 \mathrm{~N} 20.24$ & $119 \mathrm{~W} 40.50$ & 6.10 & 0.4 & $7 / 11$ & 164 & 9 & 0.05 & $\mathrm{AC}$ & $16 \mathrm{~km}$ NNE of Prosser \\
\hline
\end{tabular}


Table 4.1. Local Seismic Data, October 1, 2007 - September 30, 2008 (contd)

\begin{tabular}{|c|c|c|c|c|c|c|c|c|c|c|c|c|c|}
\hline Event ID & Туре & Date & Time & Latitude & Longitude & Depth & Mag & NS/NP & Gap & Dmin & RMS & Q & Location \\
\hline 07112810492 & & $07 / 11 / 28$ & $10: 49: 29.04$ & $46 \mathrm{~N} 20.32$ & 119W40.79 & 6.35 & 0.5 & $6 / 09$ & 166 & 9 & 0.05 & $\mathrm{AC}$ & 16 km NNE of Prosser \\
\hline 07112819432 & & $07 / 11 / 28$ & 19:43:50.98 & $46 \mathrm{~N} 20.28$ & $119 W 40.53$ & 5.47 & 1.0 & $14 / 17$ & 120 & 9 & 0.07 & $\mathrm{AB}$ & 16 km NNE of Prosser \\
\hline 07112822041 & & $07 / 11 / 28$ & 22:04:34.42 & $46 N 20.44$ & 119W40.19 & 7.74 & 0.4 & $4 / 07$ & 258 & 8 & 0.02 & $\mathrm{AD}$ & 16 km NNE of Prosser \\
\hline 07112905245 & & $07 / 11 / 29$ & $05: 25: 18.60$ & $46 \mathrm{~N} 20.30$ & 119W40.25 & 6.29 & 0.5 & $11 / 15$ & 162 & 8 & 0.05 & AC & 16 km NNE of Prosser \\
\hline 07112905260 & & $07 / 11 / 29$ & 05:24:35.88 & $46 \mathrm{~N} 20.26$ & 119W40.17 & 5.35 & 0.6 & $9 / 13$ & 161 & 8 & 0.06 & $\mathrm{AC}$ & 16 km NNE of Prosser \\
\hline 07112913350 & & $07 / 11 / 29$ & $13: 35: 25.76$ & $46 \mathrm{~N} 20.44$ & 119W40.97 & 6.14 & 0.4 & $7 / 10$ & 167 & 9 & 0.05 & $\mathrm{AC}$ & 16 km NNE of Prosser \\
\hline 07112918015 & & $07 / 11 / 29$ & 18:02:12.06 & 46N20.22 & 119W40.95 & 6.05 & 0.1 & $6 / 08$ & 167 & 9 & 0.05 & $\mathrm{AC}$ & 16 km NNE of Prosser \\
\hline 07113009394 & & 07/11/30 & 09:40:04.55 & 46N20.33 & 119W40.93 & 6.35 & 0.4 & $10 / 13$ & 167 & 9 & 0.06 & AC & 16 km NNE of Prosser \\
\hline 07120619443 & $\mathrm{X}$ & 07/12/06 & 19:44:55.85 & 46N07.64 & 119W01.05 & 0.03 & & $15 / 15$ & 122 & 9 & 0.12 & $\mathrm{AB}$ & 12 km SE of Kennewick \\
\hline 07120806063 & & 07/12/08 & 06:07:02.13 & $46 \mathrm{~N} 20.20$ & $119 W 40.27$ & 6.20 & 0.4 & $10 / 13$ & 162 & 8 & 0.04 & AC & 16 km NNE of Prosser \\
\hline 07121114304 & & $07 / 12 / 11$ & $14: 31: 08.71$ & $46 \mathrm{~N} 40.40$ & 119W29.43 & 17.96 & 0.6 & $17 / 21$ & 98 & 6 & 0.08 & $\mathrm{AB}$ & $9 \mathrm{~km}$ ENE of $100-\mathrm{K}$ Area \\
\hline 07121301044 & & 07/12/13 & 01:05:07.39 & $46 N 42.08$ & 119W30.52 & 4.94 & -0.8 & $4 / 05$ & 109 & 6 & 0.06 & $\mathrm{AD}$ & $10 \mathrm{~km}$ NE of $100-\mathrm{K}$ Area \\
\hline 07121818025 & & $07 / 12 / 18$ & 18:03:14.25 & $46 \mathrm{~N} 43.05$ & 119W29.66 & 0.02 & 0.0 & $7 / 08$ & 86 & 4 & 0.09 & $\mathrm{AB}$ & $12 \mathrm{~km}$ NE of $100-\mathrm{K}$ Area \\
\hline 07122011101 & & $07 / 12 / 20$ & $11: 10: 36.06$ & $46 N 32.42$ & 119W37.12 & 24.02 & 1.1 & $20 / 20$ & 54 & 7 & 0.09 & AA & $3 \mathrm{~km} \mathrm{SE} \mathrm{of} 200$ West \\
\hline 07122522022 & & $07 / 12 / 25$ & 22:02:50.48 & $46 \mathrm{~N} 23.24$ & 119W33.61 & 16.26 & 0.0 & $12 / 12$ & 81 & 2 & 0.08 & AA & $16 \mathrm{~km}$ WSW of 400 Area \\
\hline 08010723430 & & 08/01/07 & 23:43:29.21 & $46 N 51.54$ & 119W24.12 & 18.85 & 1.2 & $25 / 028$ & 90 & 3 & 0.10 & AA & 18 km WNW of Othello \\
\hline 08011822511 & & 08/01/18 & 22:51:41.44 & 46N28.77 & 119W22.42 & 8.36 & 0.0 & $11 / 014$ & 122 & 8 & 0.07 & $\mathrm{AB}$ & 5 km NNW of 400 Area \\
\hline 08012904402 & & 08/01/29 & 04:40:49.21 & $46 \mathrm{~N} 20.08$ & 119W40.59 & 4.09 & 0.2 & $10 / 013$ & 121 & 9 & 0.11 & BB & 16 km NNE of Prosser \\
\hline 08013001161 & & 08/01/30 & 01:1630.76 & $46 \mathrm{~N} 20.61$ & $119 W 42.50$ & 8.47 & -0.5 & $7 / 008$ & 158 & 10 & 0.26 & $\mathrm{BC}$ & 16 km NNE of Prosser \\
\hline 08020300453 & & 08/02/03 & 00:45:53.02 & 46N04.22 & 119W50.83 & 0.04 & 1.5 & $15 / 016$ & 109 & 20 & 0.13 & $\mathrm{AC}$ & 16 km SSW of Prosser \\
\hline 08020323354 & & 08/02/03 & 23:35:04.38 & $46 N 32.77$ & 119W10.81 & 22.46 & 2.3 & $33 / 033$ & 76 & 13 & 0.18 & BA & $18 \mathrm{~km} \mathrm{NE}$ of 400 Area \\
\hline 08020517393 & $\mathrm{X}$ & 08/02/05 & $17: 39: 52.71$ & 46N07.41 & 119W02.04 & 0.02 & & $7 / 007$ & 173 & 9 & 0.15 & $\mathrm{AC}$ & 11 km SE of Kennewick \\
\hline 08020519241 & $\mathrm{P}$ & 08/02/05 & $19: 24: 41.19$ & $46 N 15.59$ & 119W22.46 & 0.29 & & $8 / 008$ & 238 & 6 & 0.28 & $\mathrm{CD}$ & 7 km WSW of Richland \\
\hline 08020821563 & $\mathrm{P}$ & 08/02/08 & 21:56:04.10 & $46 N 15.78$ & 119W22.79 & 2.29 & & $11 / 011$ & 235 & 5 & 0.11 & $\mathrm{BD}$ & 7 km WSW of Richland \\
\hline 08021422295 & $\mathrm{P}$ & 08/02/14 & $22: 29: 21.22$ & $46 N 56.90$ & 119W27.66 & 1.48 & & $12 / 012$ & 97 & 2 & 0.08 & $\mathrm{AB}$ & $24 \mathrm{~km} \mathrm{SW}$ of Moses Lake \\
\hline 08022000225 & & $08 / 02 / 20$ & $00: 22: 20.07$ & 46N53.32 & 119W53.96 & 0.45 & 1.8 & $30 / 030$ & 53 & 8 & 0.17 & BB & $10 \mathrm{~km}$ SE of Vantage \\
\hline 08040521511 & & 08/04/05 & 21:51:41.92 & $46 \mathrm{~N} 20.22$ & 119W31.01 & 10.07 & -0.4 & $4 / 06$ & 192 & 6 & 0.06 & $\mathrm{AD}$ & $16 \mathrm{~km} \mathrm{SW}$ of 400 Area \\
\hline 08040720360 & & 08/04/07 & 20:36:33.29 & $46 N 32.15$ & 119W51.83 & 0.75 & 1.9 & $16 / 16$ & 124 & 11 & 0.18 & $\mathrm{BC}$ & $18 \mathrm{~km} \mathrm{~W}$ of 200 West \\
\hline 08042805175 & & $08 / 04 / 28$ & 05:18:15.09 & $46 N 43.21$ & 119W30.28 & 0.47 & -0.2 & $7 / 10$ & 92 & 5 & 0.13 & $\mathrm{AB}$ & $11 \mathrm{~km}$ NE of $100-\mathrm{K}$ Area \\
\hline 08042808021 & & $08 / 04 / 28$ & 08:02:31.71 & 46N07.91 & 119W27.90 & 7.23 & 0.4 & $9 / 11$ & 275 & 18 & 0.13 & $\mathrm{AD}$ & 22 km SW of Richland \\
\hline 08050122153 & & 08/05/01 & 22:15:57.19 & 46N33.79 & 119W49.53 & 7.06 & 0.6 & $8 / 11$ & 165 & 7 & 0.12 & $\mathrm{AC}$ & $14 \mathrm{~km} \mathrm{~W}$ of 200 West \\
\hline 08050312140 & & $08 / 05 / 03$ & $12: 14: 25.18$ & $46 \mathrm{~N} 10.86$ & 119W44.95 & 10.89 & 0.5 & $9 / 10$ & 130 & 6 & 0.09 & $\mathrm{AB}$ & $3 \mathrm{~km}$ SSE of Prosser \\
\hline
\end{tabular}


Table 4.1. Local Seismic Data, October 1, 2007 - September 30, 2008 (contd)

\begin{tabular}{|c|c|c|c|c|c|c|c|c|c|c|c|c|c|}
\hline Event ID & Type & Date & Time & Latitude & Longitude & Depth & Mag & $\mathrm{NS} / \mathrm{NP}$ & Gap & Dmin & RMS & $\mathrm{Q}$ & Location \\
\hline 08051520104 & & $08 / 05 / 15$ & 20:11:03.34 & $46 N 33.37$ & 119W52.53 & 0.56 & 0.4 & $5 / 11$ & 284 & 10 & 0.12 & $\mathrm{AD}$ & $18 \mathrm{~km} \mathrm{~W}$ of 200 West \\
\hline 08051520150 & & 08/05/15 & $20: 15: 24.88$ & 46N33.58 & 119W51.40 & 4.85 & 0.1 & $6 / 09$ & 278 & 9 & 0.05 & $\mathrm{AD}$ & $17 \mathrm{~km} \mathrm{~W}$ of 200 West \\
\hline 08051822193 & & $08 / 05 / 18$ & 22:19:54.98 & 46N09.95 & 119W33.34 & 20.53 & 3.7 & $34 / 34$ & 87 & 11 & 0.19 & BA & 17 km ESE of Prosser \\
\hline 08052122032 & & $08 / 05 / 21$ & 22:03:43.00 & $46 N 33.53$ & 119W48.86 & 7.41 & 0.2 & $8 / 08$ & 155 & 7 & 0.24 & $\mathrm{BC}$ & $14 \mathrm{~km} \mathrm{~W}$ of 200 West \\
\hline 08052220314 & & $08 / 05 / 22$ & 20:32:05.19 & 46 N32.70 & 119W53.59 & 0.02 & 0.2 & $8 / 10$ & 132 & 10 & 0.24 & $\mathrm{BC}$ & $20 \mathrm{~km} \mathrm{~W}$ of 200 West \\
\hline 08052823021 & & $08 / 05 / 28$ & 23:02:42.36 & $46 N 32.88$ & 119W49.84 & 3.42 & 0.6 & $13 / 13$ & 107 & 8 & 0.10 & $\mathrm{AB}$ & $15 \mathrm{~km} \mathrm{~W}$ of 200 West \\
\hline 08053109533 & & $08 / 05 / 31$ & 09:54:03.66 & $46 N 36.24$ & 119W51.19 & 6.73 & 0.1 & $9 / 14$ & 135 & 7 & 0.13 & $\mathrm{AB}$ & $17 \mathrm{~km} \mathrm{WNW}$ of 200 West \\
\hline 08061819150 & $\mathrm{P}$ & $08 / 06 / 18$ & $19: 15: 30.20$ & 46N07.07 & 119W27.53 & 0.41 & & $8 / 08$ & 280 & 20 & 0.31 & DD & $23 \mathrm{~km}$ SW of Richland \\
\hline 08062117355 & $\mathrm{X}$ & $08 / 06 / 21$ & $17: 36: 12.33$ & 46N39.89 & 119W33.05 & 0.38 & & $5 / 05$ & 103 & 8 & 0.02 & $\mathrm{AD}$ & $4 \mathrm{~km}$ NE of $100-\mathrm{K}$ Area \\
\hline 08062922254 & & $08 / 06 / 29$ & 22:26:03.94 & 46N20.11 & 119W40.43 & 4.97 & -0.2 & $8 / 10$ & 163 & 9 & 0.08 & $\mathrm{AC}$ & $16 \mathrm{~km}$ NNE of Prosser \\
\hline 08072207055 & & $08 / 07 / 22$ & 07:06:21.47 & $46 N 33.83$ & $119 W 42.75$ & 3.09 & -0.2 & $6 / 08$ & 142 & 5 & 0.07 & $\mathrm{AC}$ & $6 \mathrm{~km} \mathrm{~W}$ of 200 West \\
\hline 08072910002 & & 08/07/29 & $10: 00: 40.68$ & 46N52.55 & 119W34.01 & 14.20 & -0.1 & $15 / 21$ & 135 & 9 & 0.10 & $\mathrm{AB}$ & $26 \mathrm{~km} \mathrm{~N}$ of $100-\mathrm{K}$ Area \\
\hline 08080613003 & & 08/08/06 & 13:00:55.35 & $46 N 37.31$ & 119W17.96 & 15.14 & 0.4 & $20 / 24$ & 57 & 7 & 0.09 & AA & $19 \mathrm{~km}$ ENE of 200 East \\
\hline 08081814264 & & 08/08/18 & $14: 26: 59.76$ & 46N18.39 & $119 W 23.78$ & 6.98 & -0.3 & $4 / 08$ & 220 & 3 & 0.06 & $\mathrm{AD}$ & 9 km WNW of Richland \\
\hline 08082821224 & & $08 / 08 / 28$ & 21:22:59.91 & $46 N 48.42$ & 119W23.97 & 0.03 & -0.3 & $7 / 08$ & 126 & 2 & 0.10 & $\mathrm{AB}$ & $18 \mathrm{~km} \mathrm{~W}$ of Othello \\
\hline 08090607253 & & 08/09/06 & 07:25:59.44 & $46 N 42.19$ & 119W18.87 & 27.26 & 0.2 & $22 / 23$ & 84 & 9 & 0.08 & AA & $18 \mathrm{~km}$ SW of Othello \\
\hline 08090704351 & & 08/09/07 & $04: 35: 38.75$ & $46 N 22.81$ & 119W34.62 & 15.10 & -0.1 & $7 / 09$ & 194 & 1 & 0.05 & $\mathrm{AD}$ & $18 \mathrm{~km}$ WSW of 400 Area \\
\hline 08091815345 & & 08/09/18 & $15: 35: 18.66$ & $46 N 51.70$ & 119W18.02 & 15.28 & 0.0 & $14 / 18$ & 94 & 7 & 0.16 & $\mathrm{BB}$ & $11 \mathrm{~km} \mathrm{WNW}$ of Othello \\
\hline 08092920390 & $\mathrm{P}$ & $08 / 09 / 29$ & $20: 39: 29.23$ & $46 N 25.17$ & 119W00.49 & 4.26 & & $6 / 06$ & 230 & 18 & 0.17 & $\mathrm{CD}$ & 22 km NNE of Pasco \\
\hline 08093019093 & & 08/09/30 & 19:09:55.64 & 46N09.56 & 119W22.24 & 11.44 & 0.9 & $15 / 19$ & 113 & 16 & 0.14 & $\mathrm{AB}$ & $15 \mathrm{~km}$ SSW of Richland \\
\hline
\end{tabular}




\section{Explanation of Table 4.1}

Event ID: The Earthworm recording system creates the identification number. XPED uses the year, month, day, and time to create a unique number for each event.

Type: $\quad$ P is Probable Blast; $\mathrm{X}$ is Confirmed Blast; F is Felt Earthquake; blank is local earthquake.

Date: $\quad$ The year and date in Universal Time Coordinated (UTC). UTC is used throughout this report unless otherwise indicated.

Time: The origin time of the earthquake given in Coordinated Universal Time (UTC). To covert UTC to Pacific Standard Time, subtract eight hours; to Pacific Daylight Time, subtract seven hours.

Latitude: $\quad$ North latitude, in degrees and minutes, of the earthquake epicenter.

Longitude: West longitude, in degrees and minutes, of the earthquake epicenter.

Depth: The depth of the earthquake in kilometers $(\mathrm{km})$.

Mag: $\quad$ The magnitude is expressed as coda-length magnitude $\mathrm{M}_{\mathcal{C}}$, an estimate of local magnitude $\mathrm{M}_{\mathrm{L}}$ (Richter 1958). If magnitude is blank, a determination was not made.

NS/NP: $\quad$ Number of stations/number of phases used in the solutions.

Gap: $\quad$ Azimuthal gap; the largest angle (relative to the epicenter) containing no stations.

DMIN: The distance from the earthquake epicenter to the closest station.

RMS: $\quad$ The root-mean-square residual (observed arrival times minus the predicted arrival times) at all stations used to locate the earthquake. It is useful as a measure of quality of the solution only when five or more well-distributed stations are used in the solution. Good solutions are normally characterized by RMS values of less than about $0.3 \mathrm{~s}$.

Q: $\quad$ Quality factors; indicate the general reliability of the solution/location (A is best quality, D is worst). See Section 3.3 of this report, "Quality Factors."

\subsection{Quality Factors (Q)}

XPED assigns a two-letter Quality factor (Table 4.1) that indicates the general reliability of the solution (A is best quality, $\mathbf{D}$ is worst). Similar quality factors are used by the USGS for events located with the computer program HYPO71. The first letter of the quality code is a measure of the hypocenter quality based primarily on arrival time residuals. For example: Quality A requires a root-mean-square residual (RMS) less than $0.15 \mathrm{~s}$, while a RMS of $0.5 \mathrm{~s}$ or more is $\mathbf{D}$ quality (other estimates of the location uncertainty also affect this quality parameter). The second letter of the quality code is related to the spatial distribution of stations that contribute to the event location, including the number of stations (NS), the number of p-wave and s-wave phases (NP), the largest gap in event-station azimuth distribution (GAP), and the closest distance from the epicenter to a station (DMIN). Quality A requires a solution with $\mathbf{N P}>8$, GAP $<90^{\circ}$, and $\mathbf{D M I N}<5 \mathrm{~km}$ (or the hypocenter depth if it is greater than $5 \mathrm{~km}$ ). If $\mathbf{N P} \leq 5$, GAP $>180^{\circ}$, or DMIN $>50 \mathrm{~km}$, the solution is assigned Quality $\mathbf{D}$.

Uncertainties associated with estimated depths depend upon the number of stations and number of phase measurements (NS/NP) utilized in the XPED calculation. Generally speaking, if the number of phases exceeds 10 measurements, the depth estimate is considered to be reliable. In this case the second letter in the quality evaluation is either "A" or "B" (cf. Table 4.1). For example, the number of phase measurements from earthquakes ultimately classified as "deep” events typically falls within the 
10-20 measurement range; these depth estimates are considered reliable. However, the number of phase measurements from earthquakes classified as "shallow" or "intermediate" may be less than 10 readings; in this case the depth estimate is less certain and the event could be classified as occurring in the CRBG or pre-basalt layers.

Table 4.2. Crustal Velocity Model for Eastern Washington (from Rohay et al. 1985)

\begin{tabular}{||c|l|c||}
\hline $\begin{array}{c}\text { Depth to Top of } \\
\text { Velocity Layer }(\mathrm{km})\end{array}$ & \multicolumn{1}{|c||}{ Layer } & $\begin{array}{c}\text { Velocity } \\
(\mathrm{km} / \mathrm{s})\end{array}$ \\
\hline \hline 0.0 & Saddle Mountains and Wanapum Basalts and intercalated Ellensburg Formation & 3.7 \\
\hline 0.4 & Grande Ronde Basalt and pre-basalt sediments & 5.2 \\
\hline 8.5 & Crystalline basement, Layer 1 & 6.1 \\
\hline 13.0 & Crystalline basement, Layer 2 & 6.4 \\
\hline 23.0 & Sub-basement & 7.1 \\
\hline 38.0 & Mantle & 7.9 \\
\hline
\end{tabular}




\subsection{Seismic Activity - FY 2008}

\subsection{Summary}

During FY 2008, the Hanford Seismic Network recorded 1431 triggers on the seismometer system, which included 112 seismic events in the southeast Washington area and an additional 422 regional and teleseismic events. There were 74 events determined to be local earthquakes relevant to the Hanford Site (Table 4.1; Figure 5.1). The highest-magnitude event (3.7 $\mathrm{M}_{\mathrm{c}}$ ) occurred on May 18, 2008, and was located approximately $17 \mathrm{~km}$ east of Prosser at a depth of $20.5 \mathrm{~km}$. A total of 31 micro earthquakes were recorded within the Rattlesnake Mountain swarm area at depths in the 4-8 km range during the first quarter of FY 2008. The depth distribution and geographic pattern of the 74 earthquakes that occurred in the Hanford area are classified in Table 5.1 and Table 5.2.

With regard to the depth distribution, 13 earthquakes were located at shallow depths (less than $4 \mathrm{~km}$, most likely in the Columbia River basalts), 45 earthquakes were located at intermediate depths (between 4 and $9 \mathrm{~km}$, most likely in the pre-basalt sediments), and 16 earthquakes were located at depths greater than $9 \mathrm{~km}$, within the crystalline basement. Geographically, 54 earthquakes were located in swarm areas and 20 earthquakes were classified as random events.

Table 5.1. Depth Distribution of Earthquakes for FY08

\begin{tabular}{||l|c|c|c|c|l||}
\hline \multicolumn{1}{|c|}{ Category } & First Quarter & Second Quarter & Third Quarter & Fourth Quarter & FY 2008 \\
\hline \hline Shallow (0-4 km deep) & 4 & 2 & 5 & 2 & $13(18 \%)$ \\
\hline Intermediate (4-9 km deep) & 35 & 3 & 6 & 1 & $45(61 \%)$ \\
\hline Deep (greater than 9 km deep) & 5 & 2 & 3 & 6 & $16(21 \%)$ \\
\hline Total & 44 & 7 & 14 & 9 & $74(100 \%)$ \\
\hline \hline
\end{tabular}

Table 5.2. Earthquake Locations for FY 2008

\begin{tabular}{|c|c|c|c|c|c|c|}
\hline & Seismic Sources & $\begin{array}{l}\text { First Quarter } \\
10 / 01-12 / 31\end{array}$ & $\begin{array}{c}\text { Second Quarter } \\
1 / 01-3 / 31\end{array}$ & $\begin{array}{c}\text { Third Quarter } \\
\text { 4/01-6/30 }\end{array}$ & $\begin{array}{c}\text { Fourth Quarter } \\
\text { 7/01-9/30 }\end{array}$ & FY 2008 \\
\hline \multicolumn{2}{|c|}{ Geologic Structure } & & - & - & - & \\
\hline \multirow{9}{*}{$\begin{array}{l}\text { Swarm } \\
\text { Areas }\end{array}$} & Frenchman Hills & & & & & \\
\hline & $\begin{array}{l}\text { Saddle Mountains/ } \\
\text { Royal Slope }\end{array}$ & 1 & 1 & & 2 & 4 \\
\hline & Wahluke Slope & & & & 1 & 1 \\
\hline & Coyote Rapids & 5 & & 1 & & 6 \\
\hline & Wye & 1 & 1 & & & 2 \\
\hline & Cold Creek & & & 4 & & 4 \\
\hline & Rattlesnake Mountain. & 31 & 2 & 1 & & 34 \\
\hline & Horse Heaven Hills & & 1 & 2 & & 3 \\
\hline & Total for swarm areas & 38 & 5 & 8 & 3 & $54(73 \%)$ \\
\hline \multicolumn{2}{|c|}{ Random Events } & 6 & 2 & 6 & 6 & $20(27 \%)$ \\
\hline \multicolumn{2}{|c|}{ Total for all earthquakes } & 44 & 7 & 14 & 9 & 74 \\
\hline
\end{tabular}




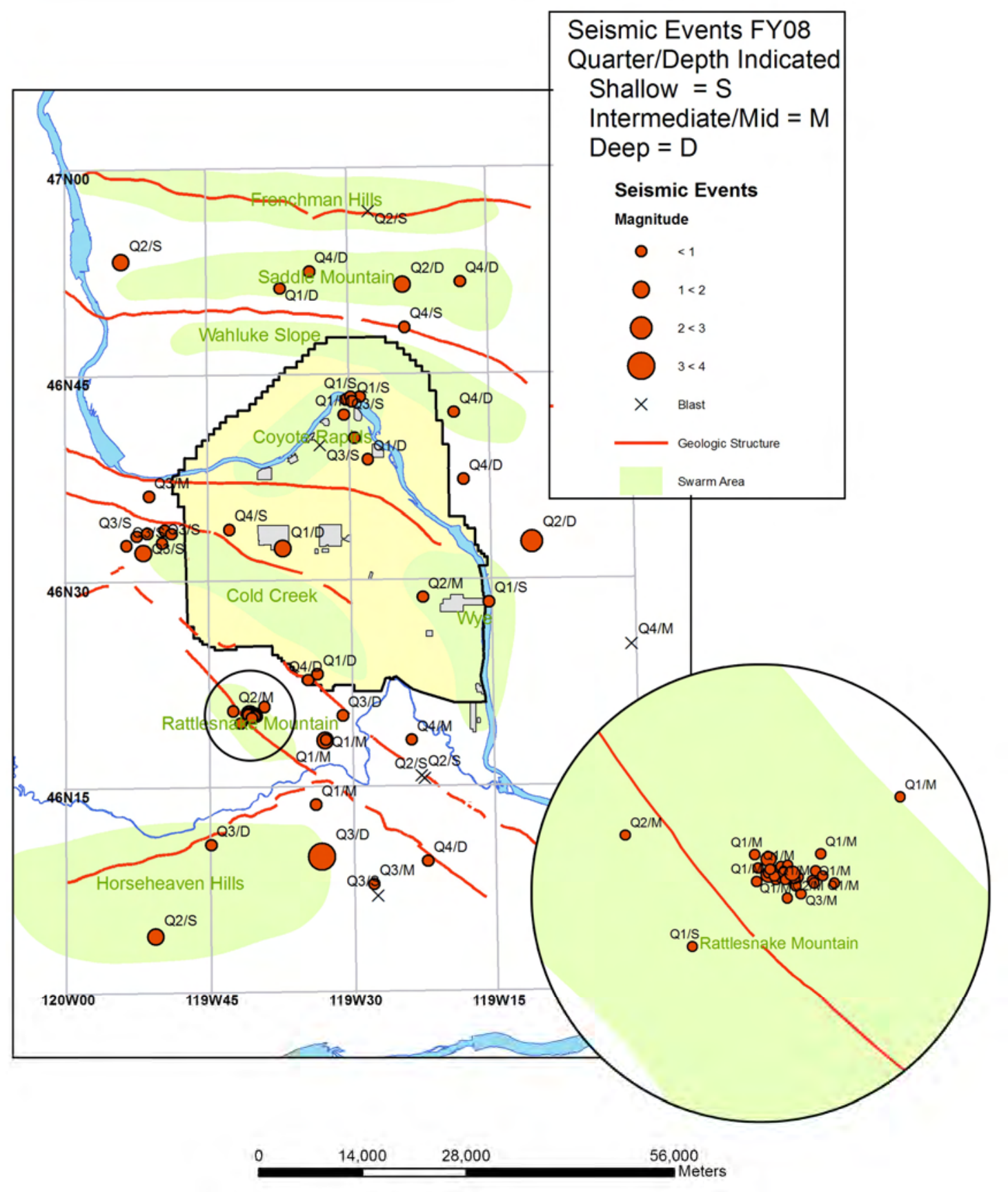

Figure 5.1. FY 2008 Earthquakes Recorded Within the Hanford Monitoring Area (October 2007 through September 2008)

\subsection{First Quarter FY 2008 Earthquakes}

For the Hanford Seismic Network, 44 local earthquakes and 1 blast event were recorded during the first quarter of FY 2008. A total of 31 micro earthquakes were recorded within the Rattlesnake Mountain 
swarm area at depths in the 4-8 km range, most likely within the pre-basalt sediments. In the following discussions, minor earthquakes refer to seismic events for which the magnitude is less than $1.0 \mathrm{M}_{\mathrm{c}}$.

\subsubsection{Location and Depth of Earthquakes}

With regard to the depth distribution, 4 earthquakes occurred at shallow depths (less than $4 \mathrm{~km}$, most likely in the Columbia River Basalt Group -CRBG), 35 earthquakes at intermediate depths (between 4 and $9 \mathrm{~km}$, most likely in the pre-basalt sediments), and 5 earthquakes were located at depths greater than $9 \mathrm{~km}$, within the crystalline basement. Geographically, 38 earthquakes occurred in swarm areas and 6 earthquakes were classified as random events.

In the past, swarms were thought to occur only at relatively shallow depths within the CRBG. During the last several years deeper based swarm events have been recorded, for example, the 31 micro earthquakes within the Rattlesnake Mountain swarm area during this quarter.

Four of the 44 recorded events with magnitude greater than $1.0 \mathrm{M}_{\mathrm{c}}$ are discussed below.

\subsubsection{Major Anticlinal Ridges}

No earthquakes were associated with the major geologic structures in the area surrounding the Hanford Site for the first quarter of FY 2008.

\subsubsection{Earthquake Swarm Areas}

Thirty-eight earthquakes were characterized as swarm events in the first quarter of FY 2008.

\section{Rattlesnake Mountain Swarm Area}

During the quarter, 31 micro earthquakes were recorded in the Rattlesnake Mountain swarm area at a range of depths 3.5-8.2 km. The proximity of epicenters (Figure 5.2) suggests that these earthquakes have a common source with the most reliable depth estimates between 4.3 and $5.5 \mathrm{~km}$. For this reason, the swarm events are considered to have occurred within the pre-basalt sediments, deeper than the known geologic structure expressed at the surface. On November 19 and November 25, events measuring 1.2 and $1.5 \mathrm{M}_{\mathrm{c}}$ were recorded within this swarm area.

\subsubsection{Random or Floating Events}

Two events (October 3 and December 20) measuring 1.4 and $1.1 \mathrm{M}_{\mathrm{c}}$ were recorded and classified as random events. The October 3 event was located east of Rattlesnake Mountain with estimated depth $7.3 \mathrm{~km}$, most likely within the pre-basalt sediments. The December 20 event was located within the crystalline basement at depth $24.0 \mathrm{~km}$ beneath the 200 West Area.

\subsection{Second Quarter FY 2008 Earthquakes}

For the Hanford Seismic Network, seven local earthquakes and four blast events were recorded during the second quarter of FY 2008. 


\subsubsection{Location and Depth of Earthquakes}

With regard to the depth distribution, two earthquakes occurred at shallow depths (less than $4 \mathrm{~km}$, most likely in the Columbia River basalts), three earthquakes at intermediate depths (between 4 and $9 \mathrm{~km}$, most likely in the pre-basalt sediments), and two earthquakes were located at depths greater than $9 \mathrm{~km}$, within the crystalline basement. Geographically, five earthquakes occurred in swarm areas and two earthquakes were classified as random events.

Four of the seven recorded events with magnitude greater than $1.0 \mathrm{M}_{\mathrm{c}}$ are discussed below.

\subsubsection{Major Anticlinal Ridges}

No earthquakes were associated with the major geologic structures in the area surrounding the Hanford Site for the second quarter of FY 2008.

\subsubsection{Earthquake Swarm Areas}

Five earthquakes were characterized as swarm events in the second quarter of FY 2008.

\section{Saddle Mountains Swarm Area}

On January 7, an earthquake measuring $1.2 \mathrm{M}_{\mathrm{c}}$ was recorded at depth approximately $18.9 \mathrm{~km}$ within the crystalline basement.

\section{Horse Heavens Hills Swarm Area}

On February 3, an earthquake measuring $1.5 \mathrm{M}_{\mathrm{c}}$ was recorded at depth approximately $0.04 \mathrm{~km}$ and considered to be within the CRBG.

\subsubsection{Random or Floating Events}

The largest event recorded by the network during the second quarter (February 3 - magnitude $2.3 \mathrm{M}_{\mathrm{c}}$ ) was located northeast of Richland in Franklin County at a depth of $22.5 \mathrm{~km}$. This event occurred within the crystalline basement. On February 20, a $1.8 \mathrm{M}_{\mathrm{c}}$ event was recorded at depth $0.5 \mathrm{~km}$ and located near the Columbia River west of the Saddle Mountain swarm area. This event occurred within the CRBG.

\subsection{Third Quarter FY 2008 Earthquakes}

For the Hanford Seismic Network (HSN), 14 local earthquakes and 2 blast events were recorded during the third quarter of FY 2008. The largest event recorded by the network during the third quarter occurred on May 18 (magnitude $3.7 \mathrm{M}_{\mathrm{c}}$ ) and was located approximately $17 \mathrm{~km}$ east of Prosser at a depth of $20.5 \mathrm{~km}$ within the crystalline basement. This earthquake was the highest magnitude event recorded since 1975 in the vicinity of the Hanford Site (between $46-47^{\circ}$ north latitude and between $119-120^{\circ}$ west longitude). The event, not reported as being felt on the Hanford Site or causing any damage, was communicated to the PNNL Operations Center per HSAP communications procedures. The event is not considered to be significant with regard to site safety and not unprecedented given the site's seismic history. 
Two of the fourteen recorded events with magnitude greater than $1.0 \mathrm{M}_{\mathrm{c}}$ are discussed below.

\subsubsection{Location and Depth of Earthquakes}

With regard to the depth distribution, five earthquakes were located at shallow depths (less than $4 \mathrm{~km}$, most likely in the Columbia River basalts), six earthquakes were located at intermediate depths (between 4 and $9 \mathrm{~km}$, most likely in the pre-basalt sediments), and three earthquakes were located at depths greater than $9 \mathrm{~km}$, within the crystalline basement. Geographically, eight earthquakes were located in swarm areas and six earthquakes were classified as random events.

\subsubsection{Major Anticlinal Ridges}

No earthquakes were associated with the major geologic structures in the area surrounding the Hanford Site for the third quarter of FY 2008.

\subsubsection{Earthquake Swarm Areas}

Eight earthquakes were characterized as swarm events in the third quarter of FY 2008.

\section{Cold Creek Swarm Area}

A $1.9 \mathrm{M}_{\mathrm{c}}$ magnitude event was recorded on April 7 at depth approximately $0.8 \mathrm{~km}$ within the CRBG.

\section{Horse Heavens Hills Swarm Area}

The largest magnitude event recorded since 1975 occurred on May 18 (magnitude $3.7 \mathrm{M}_{\mathrm{c}}$ ) and located approximately $17 \mathrm{~km}$ east of Prosser at a depth of $20.5 \mathrm{~km}$ within the crystalline basement. The Hanford SMA network was triggered by this event and the SMA recordings are discussed in Section 6.0.

The Pacific Northwest Seismic Center classifies this event as minor since the magnitude did not exceed 4.0 $\mathrm{M}_{\mathrm{c}}$. Other notable events recorded by the HSN include 1) a $4.4 \mathrm{M}_{\mathrm{c}}$ event in 1973 at depth $3.3 \mathrm{~km}$ with epicenter in the Saddle Mountain swarm area, 2) a $3.8 \mathrm{M}_{\mathrm{c}}$ event in 1971 at depth $4.0 \mathrm{~km}$ with epicenter in the Coyote Rapids swarm area, and 3) a $3.8 \mathrm{M}_{\mathrm{c}}$ event in 1975 at depth $11.0 \mathrm{~km}$ with epicenter in the Horse Heavens Hills swarm area. Other events with magnitude greater than $3.0 \mathrm{M}_{\mathrm{c}}$ with epicenters within the Horse Heaven Hills swarm (depths between 9.3 and $21.3 \mathrm{~km}$ ) occurred in 1979 (3.6 $\mathrm{M}_{\mathrm{c}}$ ), 1975 (3.3 $\mathrm{M}_{\mathrm{c}}$ ), and twice in 1995 (3.1 $\mathrm{M}_{\mathrm{c}}$ both times).

\subsubsection{Random or Floating Events}

Six minor events were recorded during the third quarter of FY 2008.

\subsection{Fourth Quarter FY 2008 Earthquakes}

During the fourth quarter of FY 2008, the HSN recorded 304 triggers, which included 17 events located in the southeast Washington area and an additional 104 regional and teleseismic events. Ten events were located in the Hanford vicinity for this report and included one blast event (Table 4.1). 


\subsubsection{Location and Depth of Earthquakes}

The depth distribution and geographic pattern of the nine earthquakes that occurred in the Hanford area are classified in Table 5.1 and Table 5.2. Epicenters of these events are shown in Figure 5.2. The depth distribution of these events is shown in Figure 5.3 with the events projected onto the 119W30 Longitude cross section.

With regard to the depth distribution, two earthquakes were located at shallow depths (less than $4 \mathrm{~km}$, most likely in the Columbia River basalts), one earthquake was located at intermediate depths (between 4 and $9 \mathrm{~km}$, most likely in the pre-basalt sediments), and six earthquakes were located at depths greater than $9 \mathrm{~km}$, within the crystalline basement. Geographically, three earthquakes were located in swarm areas and six earthquakes were classified as random events.

In the following discussion, minor earthquakes refer to seismic events for which the magnitude is less than $1.0 \mathrm{M}_{\mathrm{c}}$.

\subsubsection{Major Anticlinal Ridges}

No earthquakes were associated with the major geologic structures in the area surrounding the Hanford Site for the fourth quarter of FY 2008.

\subsubsection{Earthquake Swarm Areas}

Three earthquakes were characterized as swarm events in the fourth quarter of FY 2008.

\section{Saddle Mountains Swarm Area}

Two minor events were recorded on July 29 and September 18 and located at depths 14.2 and $15.3 \mathrm{~km}$ within the crystalline basement.

\section{Wahluke Slope Swarm Area}

A minor event was recorded on September 6 and located at depth $27.3 \mathrm{~km}$ within the crystalline basement.

\subsubsection{Random or Floating Events}

Six minor events were recorded during the fourth quarter of FY 2008. A minor event with epicenter located approximately $6 \mathrm{~km}$ west of the 200 West Area at depth $3.1 \mathrm{~km}$ (CRBG) was recorded on July 22. A minor event with epicenter located $19 \mathrm{~km}$ northeast of the 200 East Area (Franklin County) at depth $15.1 \mathrm{~km}$ (crystalline basement) was recorded on August 6. A minor event with epicenter located approximately $9 \mathrm{~km}$ west of Richland at depth $7.0 \mathrm{~km}$ (pre-basalt sediments) was recorded on August 18 . A minor event with epicenter located $18 \mathrm{~km}$ west of Othello and north of the Hanford site at depth $0.03 \mathrm{~km}$ (CRBG) was recorded on August 28; this event is considered to be located well above the Saddle Mountain fault. A minor event with epicenter located approximately $18 \mathrm{~km}$ southwest of the 400 Area south of the Hanford Site at depth $15.1 \mathrm{~km}$ (crystalline basement) was recorded on September 7; this 
event is considered to be located substantially below known fault structure. A minor event with epicenter located approximately $15 \mathrm{~km}$ south of Richland at depth $11.4 \mathrm{~km}$ (crystalline basement) was recorded on September 30.

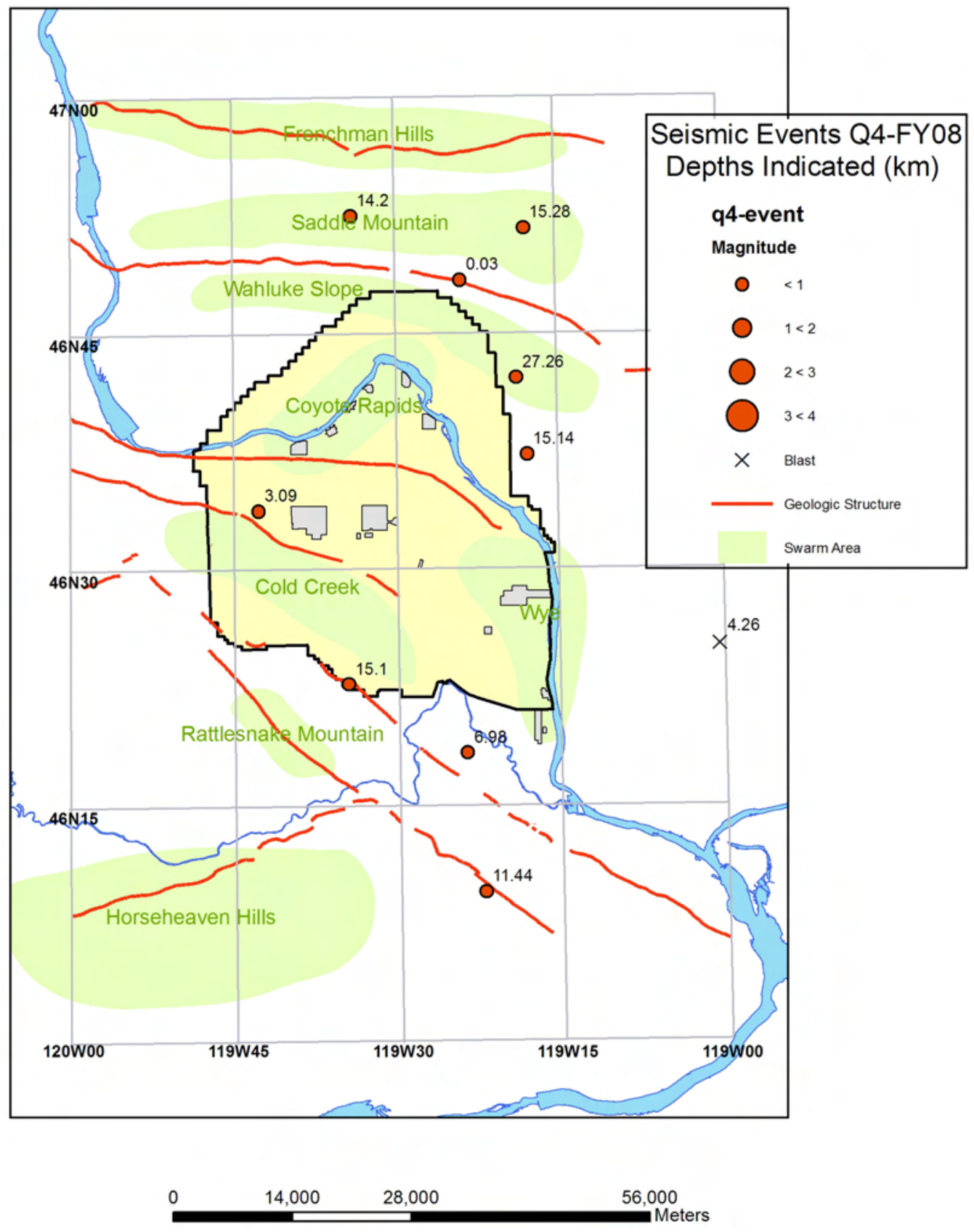

Figure 5.2. Earthquakes Occurring in the Hanford Monitoring Area Between July 1, 2008 and September 30, 2008 (fourth quarter) 

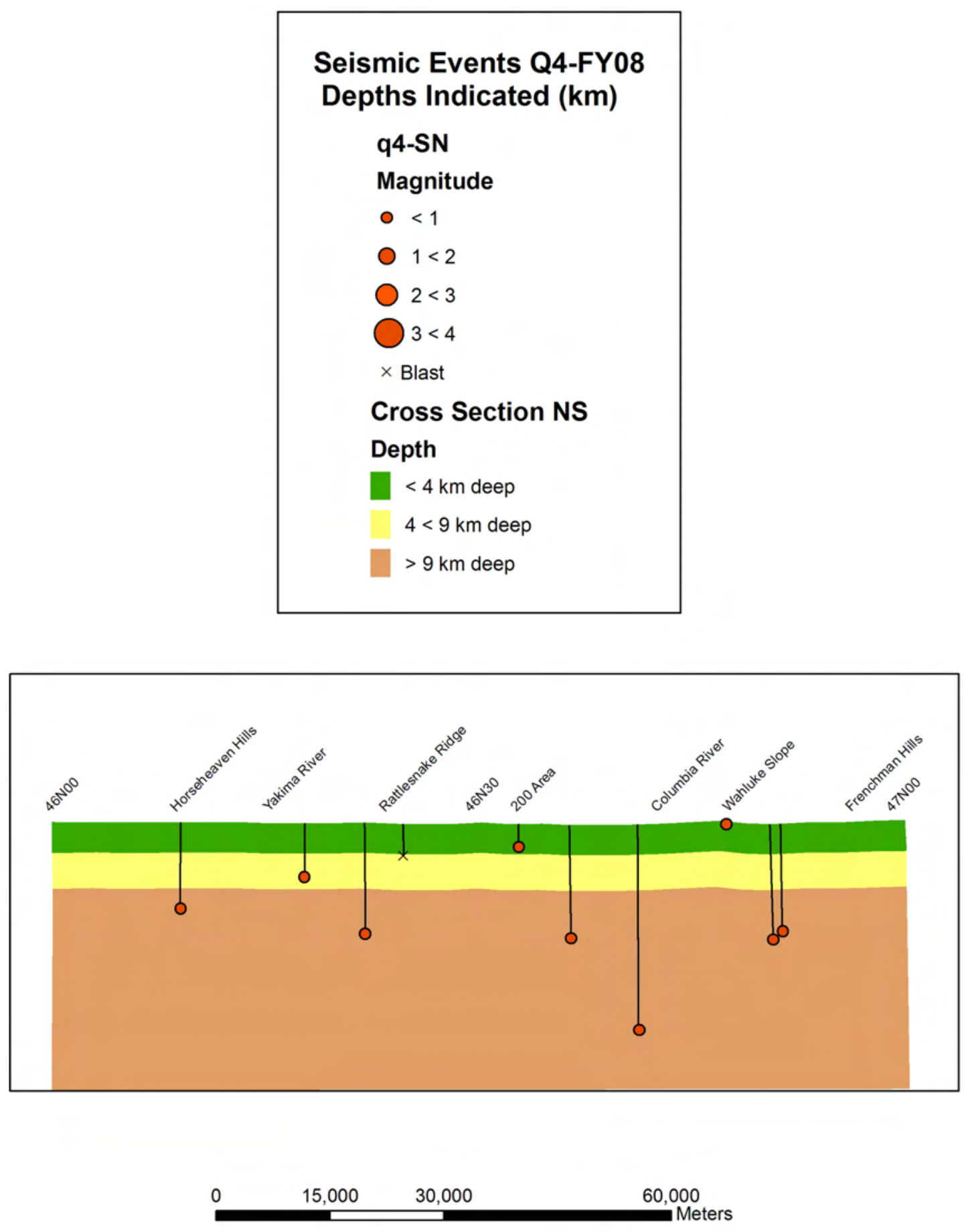

Figure 5.3. Cross-Sectional Depiction (along 119W30 longitude) of Earthquakes Occurring in the Hanford Monitoring Area between July 1, 2008 and September 30, 2008 (fourth quarter) 


\subsection{Strong Motion Accelerometer Operations}

The Hanford SMA network has been in continuous operation since November 20, 1998. Initially, the threshold used in the SMA network was $0.1 \% \mathrm{~g}$. In 2006, the trigger threshold was reduced to $0.02 \% \mathrm{~g}$ when new instruments with greater storage capacity were installed. The lower trigger threshold saves the ground motion recordings for smaller, non-damaging earthquakes that can be useful in estimating the ground motion expected from larger earthquakes, and to confirm correct operation of the instruments by analyzing the smaller-amplitude triggers (see Section 2.2).

\subsection{Fourth Quarter FY 2008 Triggers of the Hanford SMA Network}

The Hanford SMA network was triggered by a $4.2 \mathrm{M}_{\mathrm{c}}$ seismic event that occurred on July 14, 2008, with epicenter located approximately $11.5 \mathrm{~km}$ southeast of Maupin, Oregon, at depth $17.4 \mathrm{~km}$ within the crystalline basement. This event, located outside of the Hanford monitoring window, showed a peak horizontal acceleration of $0.023 \%$ g (recorded at the 400 Area SMA, Figure 6.1), approximately 90 times lower that the reportable action level for Hanford facilities (2\% g). No action was required.

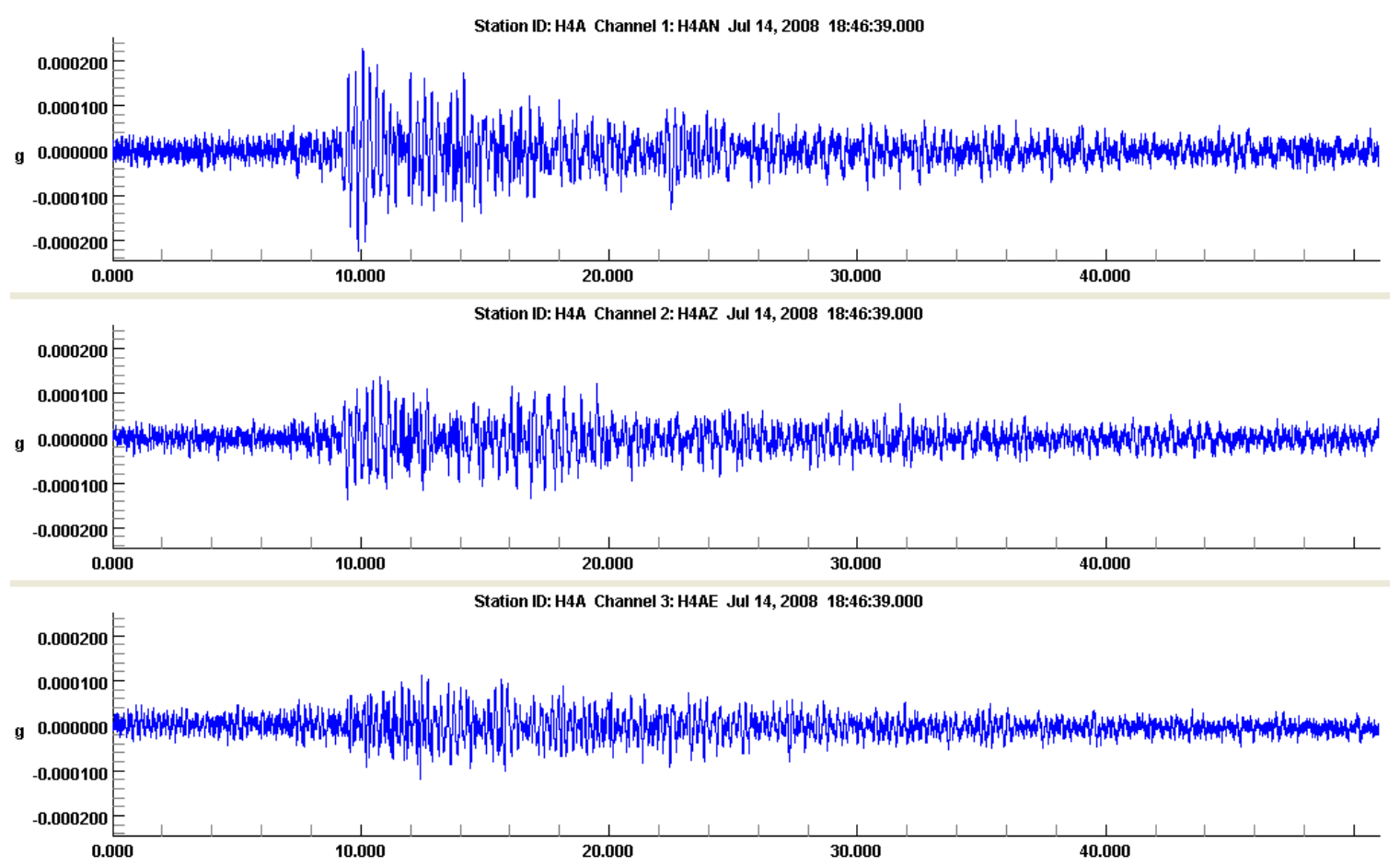

Figure 6.1. July 14, 2008 Acceleration Time Histories at 400 Area SMA from Maupin, Oregon, Earthquake

\subsection{FY 2008 Triggers of the Hanford SMA Network}

The Hanford SMA network was triggered by the $2.3 \mathrm{M}_{\mathrm{c}}$ seismic event that occurred on February 3, 2008. That event was recorded on the 300 Area and the 400 Area SMA units. At the 400 Area SMA station, which is located approximately $18 \mathrm{~km}$ from the epicenter of the event, the maximum horizontal 
and vertical accelerations were measured at $0.026 \% \mathrm{~g}$ (Figure 6.2). The reportable action level of $2 \% \mathrm{~g}$ for Hanford facilities is approximately 80 times larger than the peak accelerations observed at the 300 and 400 Areas and no action was required.

The Hanford SMA network was triggered by the $3.7 \mathrm{M}_{\mathrm{c}}$ seismic event that occurred on May 18, 2008. That event was recorded on the 200 East Area, 300 Area, and 400 Area SMA units. Data shown in Figure 6.3 was plotted from event files downloaded from the 300 Area SMA unit. The maximum acceleration recorded at the SMA stations (0.17\% at 300 Area) was 12 times smaller than the reportable action level ( $2 \% \mathrm{~g})$ for Hanford Site facilities. The Pacific Northwest Seismic Center produced a shake map for the May 18, 2008 event (Figure 6.4) that predicted "light" shaking and no damage on the Hanford Site. No reports of ground shaking or facility damage were received from Hanford Site personnel.

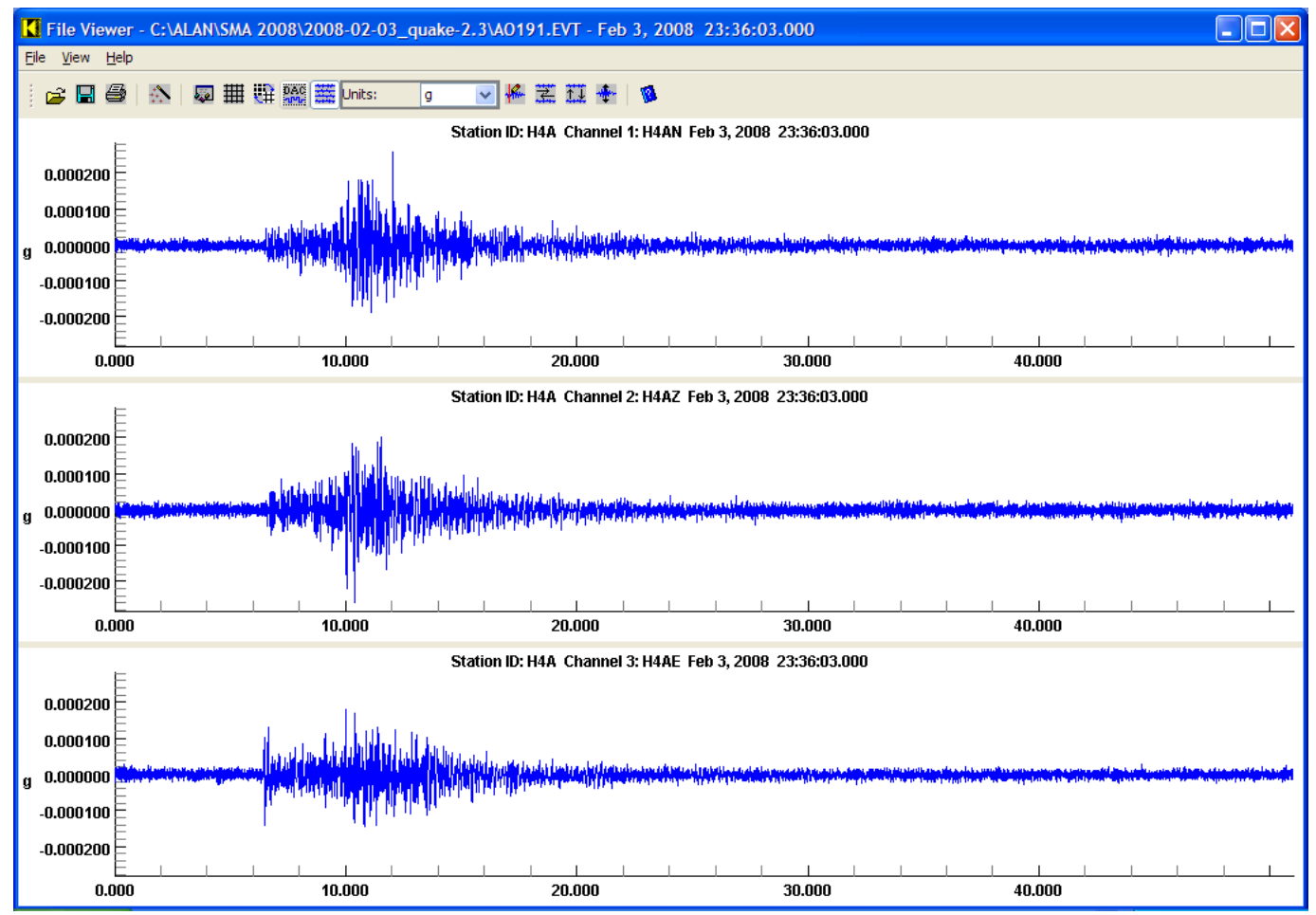

Figure 6.2. February 3, 2008 Micro Earthquake Acceleration Time Histories at 400 Area SMA 


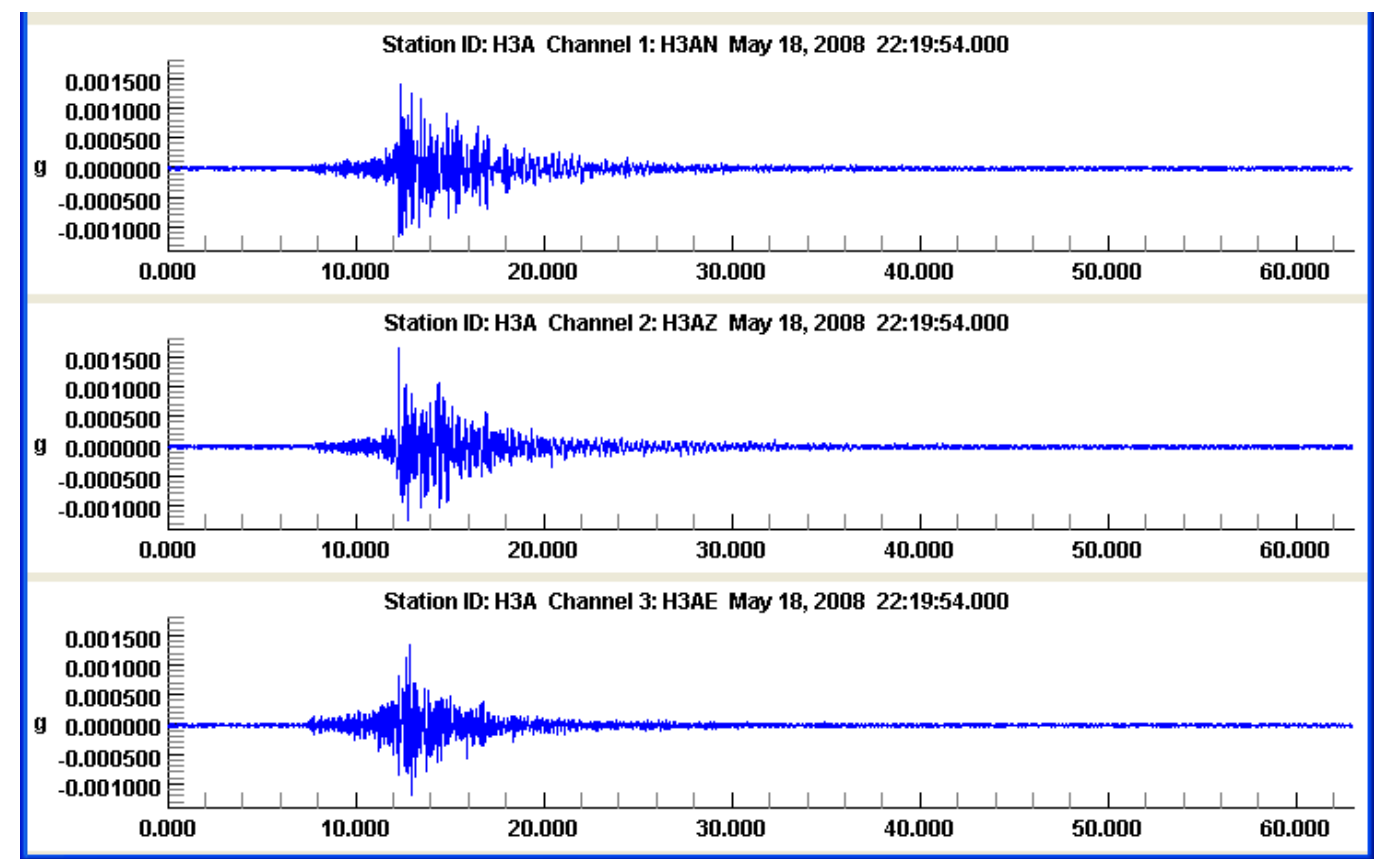

Figure 6.3. May 18, 2008 Micro Earthquake Acceleration Time Histories at 300 Area SMA 


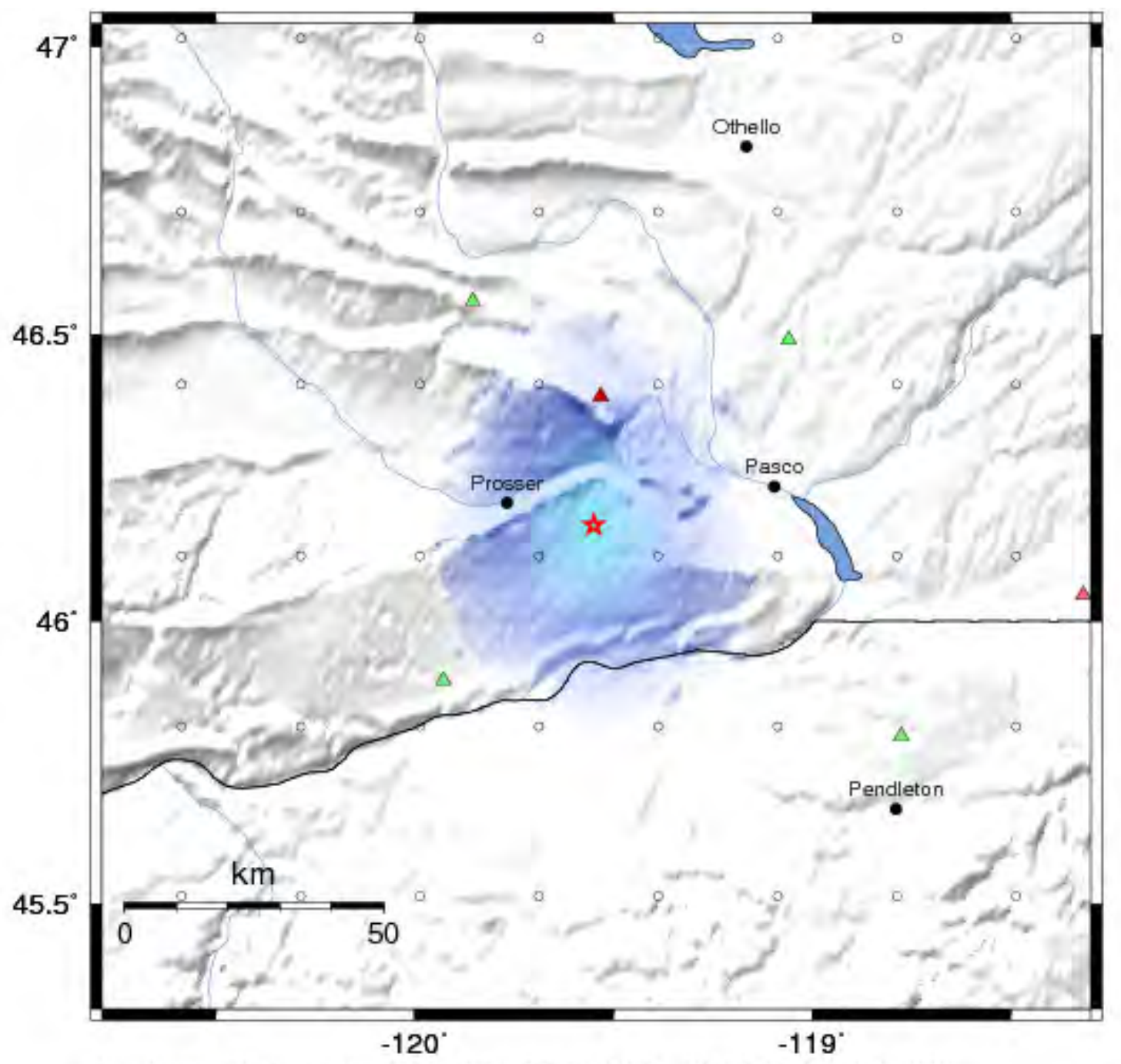

Map Version 1 Processed Sun May 18, 2008 04:39:37 PM PDT, -- NOT REVIEWED BY HUMAN

\begin{tabular}{|c|c|c|c|c|c|c|c|c|c|}
\hline $\begin{array}{l}\text { PERCEIVED } \\
\text { SHAKINGG }\end{array}$ & Not felt & Weak & Light & Moderate & Strong & Very strong & Severe & Violent & Extreme \\
\hline $\begin{array}{l}\text { POTENTIAL } \\
\text { DAMAGE }\end{array}$ & nono & none & none & Vory light & Light & Moderate & Moderate'Heavy & Hoavy & Vory Hoavy \\
\hline PEAK ACC.(\%g) & $<.17$ & $.17-1.4$ & $1.4-3.9$ & $3.9-9.2$ & $9.2-18$ & $18-34$ & $34-65$ & $65-124$ & $>124$ \\
\hline PEAK VEL.(cm/s) & $<0.1$ & $0.1-1.1$ & $1.1-3.4$ & $3.4-8.1$ & $8.1-16$ & $16-31$ & $31-60$ & $60-116$ & $>116$ \\
\hline $\begin{array}{l}\text { INSTRUMENTAL } \\
\text { INTENSITY }\end{array}$ & I & III-III & IV & V & VI & VII & VIII & IX & $x+$ \\
\hline
\end{tabular}

Figure 6.4. Shake Map of May 18, 2008 Event (courtesy of Pacific Northwest Seismic Center) 


\subsection{Capabilities in the Event of a Significant Earthquake}

The SMA network was designed to provide ground motion data in areas at the Hanford Site that have high densities of people and/or facilities containing hazardous materials, to ensure that the Hanford Site is in compliance with DOE Order 420.1B, Chapter IV, Section 3.d, "Seismic Detection.” The network also allows the HSAP to support Hanford Site emergency services organizations in complying with DOE Order G 420.1-1, Section 4.7, “Emergency Preparedness and Emergency Communications,” by providing area ground motion data in the event of an earthquake on the Hanford Site. This section summarizes the capabilities of the HSAP in the event of an earthquake at Hanford.

Historically, only a few facilities at the Hanford Site had instruments to provide data on peak ground accelerations or any type of ground motion. The current SMA instruments were located so that if an earthquake occurred, ground motion data would be readily available to assess the damage at the 100-K Area, the 200 East and West Areas, and the 300 and 400 Area facilities, which have the greatest concentration of people and also contain hazardous materials (Moore and Reidel 1996).

Many facilities at the Hanford Site have undergone various degrees of seismic analysis, either during design or during requalification. Although the seismic design of a building may be known, when an earthquake is "felt" in a facility on the Hanford Site, a determination must be made as to the extent of damage before it can be reoccupied and the systems restarted. A "felt" earthquake may not cause any significant damage to a building but, without adequate characterization of the ground motion, initial determination of the building's possibility of having damage may be impossible.

In the event of a major regional earthquake such as the 2001 Nisqually event, building managers, emergency directors, and engineers can obtain ground motion data recorded by the SMA network from the HSAP in the Sigma V Building. This is done through the Hanford Site Emergency Services organization. Normal hours of operation for the HSAP are between 6 a.m. and 4:30 p.m., Monday through Friday. If a SMA is triggered, the HSAP will download events that were recorded and determine the peak ground accelerations. This information is then passed on to Hanford Site Emergency Services personnel where the facility engineers can use the data to determine if the ground motion exceeded, is equal to, or is less than the building design. This, along with assessments from trained engineers, allows the facility manager to make a rapid and cost-effective determination on whether a building is safe to re-occupy or should not be used until it has been inspected in more detail. Buildings that have designs exceeding the recorded ground motion could be put back into service very quickly; buildings with designs that are very close to or less than measured ground motion could be given priority for onsite damage inspections. 


\subsection{References}

Campbell NP. 1989. "Structural and Stratigraphic Interpretation of Rocks under the Yakima Fold Belt, Columbia Basin, Based on Recent Surface Mapping and Well Data.” In Volcanism and Tectonism in the Columbia River Flood-Basalt Province, SP Reidel and PR Hooper (eds.), Special Paper 239, pp. 209-222. Geological Society of America, Boulder, Colorado.

Crosson RS. 1972. "Small Earthquakes, Structure and Tectonics of the Puget Sound Region.” Bulletin of the Seismological Society of America 62(5):1133-1171.

DOE. 1988. Site Characterization Plan for the Reference Location, Hanford, Washington-

Consultation Draft. DOE/RW-0164, Vol. 1, U.S. Department of Energy, Washington, D.C.

DOE Order 420.1B, Chapter IV, Section 3.d. “Seismic Detection.” U.S. Department of Energy, Washington, D.C.

DOE Order G 420.1-1, Section 4.7. “Emergency Preparedness and Emergency Communications.” U.S. Department of Energy, Washington, D.C.

Fenneman NM. 1931. Physiography of Western United States. McGraw-Hill Book Company, Inc., New York.

Geomatrix. 1996. Probabilistic Seismic Hazard Analysis, DOE Hanford Site, Washington. WHC-SDW236A-TI-002, Rev. 1, Westinghouse Hanford Company, Richland, Washington.

Moore C and SP Reidel. 1996. Hanford Site Seismic Monitoring Instrumentation Plan. WHC-SD-GNER-30036, Westinghouse Hanford Company, Richland, Washington.

Reidel SP and KR Fecht. 1994a. Geologic Map of the Richland 1:100,000 Quadrangle, Washington. Open File Report 94-8, Division of Geology and Earth Resources, Washington State Department of Natural Resources, Olympia.

Reidel SP and KR Fecht. 1994b. Geologic Map of the Priest Rapids 1:100,000 Quadrangle, Washington. Open File Report 94-13, Division of Geology and Earth Resources, Washington State Department of Natural Resources, Olympia.

Reidel SP, NP Campbell, KR Fecht, and KA Lindsey. 1994. "Late Cenozoic Structure and Stratigraphy of South-Central Washington.” In Regional Geology of Washington State, E Cheney and R Lasmanis (eds.), Bulletin 80, pp. 159-180. Division of Geology and Earth Resources, Washington State Department of Natural Resources, Olympia.

Reidel SP, KR Fecht, MC Hagood, and TL Tolan. 1989. "Geologic Development of the Central Columbia Plateau.” In Volcanism and Tectonism in the Columbia River Flood-Basalt Province, SP Reidel and PR Hooper (eds.), Special Paper 239, pp. 247-264. Geological Society of America, Boulder, Colorado.

Richter CF. 1958. Elementary Seismology. W. H. Freeman \& Company, San Francisco, California. 
Rohay AC, DW Glover, and SD Malone. 1985. Time-Term Analysis of Upper Crustal Structure in the Columbia Basin, Washington. RHO-BW-SA-435 P, Rockwell Hanford Operations, Richland, Washington.

Rohay AC, MD Sweeney, DC Hartshorn, RE Clayton, and JL Devary. 2008a. First Quarter Seismic Report for Fiscal Year 2008. PNNL-17412, Pacific Northwest National Laboratory, Richland, Washington.

Rohay AC, MD Sweeney, DC Hartshorn, RE Clayton, and JL Devary. 2008b. Second Quarter Seismic Report for Fiscal Year 2008. PNNL-17654, Pacific Northwest National Laboratory, Richland, Washington.

Rohay AC, MD Sweeney, DC Hartshorn, RE Clayton, and JL Devary. 2008c. Third Quarter Seismic Report for Fiscal Year 2008. PNNL-17830, Pacific Northwest National Laboratory, Richland, Washington. 
PNNL-18134

\section{Distribution}

No. of

\section{Copies}

\section{OFFSITE}

Administrator

Kennewick General Hospital

P.O. Box 6128

Kennewick, WA 99336

R. Carson

Department of Geology

Whitman College

345 Bayer Avenue

Walla Walla, WA 99362

T. Conrads

Parsons Constructors, Inc.

3005 E. Ainsworth Street

Pasco, WA 99301

J. Schelling

Washington Emergency Management

Division

Building 20, M/S: TA-20

Camp Murray, WA 98430-5122

Idaho Geological Survey

Morrill Hall

University of Idaho

P.O. Box 443014

Moscow, ID 83844-3014

J. Kimball

Defense Nuclear Facilities Safety Board 625 Indiana Avenue NW, Suite 700

Washington, DC 20004
No. of

Copies

S. Lilligren

Nez Perce Tribe

P.O. Box 365

Lapwai, ID 83540

J. Litehiser

Bechtel National, Inc.

P.O. Box 193965

San Francisco, CA 94119-3965

2 Oregon Department of Geology and Mineral Industries

Suite 965, 800 NE Oregon Street \#28

Portland, OR 97232

ATTN: Library

I. Madin

N. Rasmussen

3140 Ravenshoe Drive

Las Vegas, NV 89134

S. P. Reidel

WSU Tri-Cities

2710 University Drive

Richland, WA 99354

P. Rizzo

105 Mall Boulevard

Suite 270E, Expo Mart

Monroeville, PA 15146

M. Stickney

Montana Bureau of Mines and Geology

Montana Tech University

Earthquake Studies Office

1300 West Park Street

Butte, MT 59701-8997 
PNNL-18134

No. of

Copies

3 University of Washington

Seismology Laboratory

Department of Earth and Space Sciences

Box 351310

Seattle, WA 98195-1310

ATTN: P. Bodin

R. Steele

J. Vidale

2 University of Washington

U.S. Geological Survey

Department of Earth and Space Sciences

Box 351310

Seattle, WA 98195-1310

ATTN: C. Weaver

T. Yelin

U.S. Fish and Wildlife Service

3250 Port of Benton Boulevard

Richland, WA 99352

U.S. Geological Survey

Mail Stop 977

345 Middlefield Road

Menlo Park, CA 94025

ATTN: T. Brocher

2 Washington Division of Geology and Earth

Resources

P.O. Box 47007

Olympia, WA 98504-7007

ATTN: Library

T. Walsh

Washington State University

Department of Geology

P.O. Box 643420

Pullman, WA 99164-2812

R. Whale

Shell E\&P

200 N. Dairy Ashford

Houston, TX 77079
No. of

Copies

I. G. Wong

URS Corporation

1333 Broadway, Suite 800

Oakland, CA 94612

J. Zollweg

Boise State University

Department of Geosciences

Boise, ID 83725

\section{ONSITE}

6 DOE Richland Operations Office

B. L. Charboneau

A6-33

K. L. Flynn

A6-35

T. Y. Hale

A7-89

R. D. Hildebrand

A6-38

J. G. Morse

A6-38

Y. T. Sherman

A6-35

\section{DOE Office of River Protection}
R. A. Gilbert
H6-60
M. R. Moreno
H6-60

Washington River Protection Solutions

F. M. Mann

H6-03

7 CH2M Hill Plateau Remediation Co.

M. E. Brown

G5-51

J. T. Curtis

B3-15

S. A. Fargo

H8-60

S. M. Faulk

A3-05

B. H. Ford

E6-44

D. G. Horton

B6-06

M. I. Wood

H8-44 
PNNL-18134

No. of

Copies

Stoller

R. G. McCain $\quad$ B2-62

Washington State Department of Ecology

J. Caggiano

H0-57
No. of

Copies

16 Pacific Northwest National Laboratory

R. E. Clayton K6-75

J. L. Devary (5) K6-96

D. C. Hartshorn K6-75

B. E. Opitz K6-75

A. C. Rohay K6-75

M. D. Sweeney (5) K6-75

Hanford Technical Library (2) P8-55 


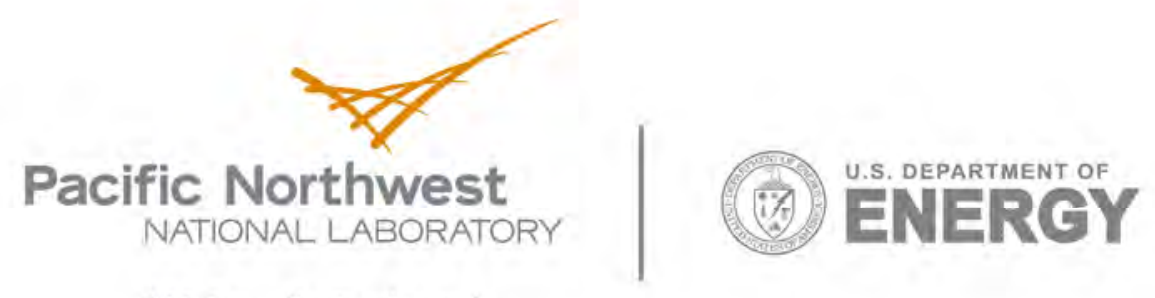

902 Battelle Boulevard

P.O. Box 999

Richland, WA 99352

1-888-375-PNNL (7665)

www.pnl.gov 